\title{
Novel Transgenic Mouse Model for Studying Human Serum Albumin as A Biomarker of Carcinogenic Exposure
}

\author{
Jonathan Sheng ${ }^{\S, £}$, Yi Wang ${ }^{\ddagger, £}$, Robert J. Turesky ${ }^{\ddagger},{ }^{\star}$, Kerri Kluetzman ${ }^{\S}$, Qing-Yu Zhang ${ }^{\S}$, \\ and Xinxin Ding ${ }^{\dagger, *}$ \\ §Wadsworth Center, New York State Department of Health, Albany, NY 12201 \\ ¥Masonic Cancer Center and Department of Medicinal Chemistry, University of Minnesota, \\ Minneapolis, MN 55455 \\ ${ }^{\dagger}$ College of Nanoscale Science, SUNY Polytechnic Institute, Albany, NY 12203
}

\section{Abstract}

\begin{abstract}
Albumin is a commonly used serum protein for studying human exposure to xenobiotic compounds, including therapeutics and environmental pollutants. Often, the reactivity of albumin with xenobiotic compounds is studied ex vivo with human albumin or plasma/serum samples. Some studies have characterized the reactivity of albumin with chemicals in rodent models; however, differences between the orthologous peptide sequences of human and rodent albumins can result in formation of different types of chemical-protein adducts with different interaction sites or peptide sequences. Our goal is to generate a human albumin transgenic mouse model that can be used to establish human protein biomarkers of exposure to hazardous xenobiotics for human risk assessment via animal studies. We now have developed a human albumin transgenic mouse model and characterized the genotype and phenotype of transgenic mice. The presence of human albumin gene in the model mouse genome was confirmed by genomic PCR analysis, while the liver-specific expression of the transgenic human albumin mRNA was validated by RT-PCR analysis. Further immunoblot and mass-spectrometry analyses indicate that the transgenic human albumin protein is a full-length, mature protein, which is less abundant than the endogenous mouse albumin that coexists in the transgenic mouse serum. The transgenic protein was able to form ex vivo adducts with a genotoxic metabolite of 2-amino-1-methyl-6-phenylimidazo[4,5$b$ ]pyridine, a procarcinogenic heterocyclic aromatic amine formed in cooked meat. This novel human albumin transgenic mouse model will facilitate the development and validation of albumincarcinogen adducts as biomarkers of xenobiotic exposure and/or toxicity in humans.
\end{abstract}

\section{Graphical Abstract}

\footnotetext{
*Corresponding Authors: Xinxin Ding, College of Nanoscale Science, SUNY Polytechnic Institute, 257 Fuller Road, Albany, NY 12203, USA. Tel: +1 518-956-7057. xding@ sunypoly.edu. Robert J. Turesky, Masonic Cancer Center and Department of Medicinal Chemistry, Cancer and Cardiology Research Building, University of Minnesota, 2231 6th Street, Minneapolis, MN 55455, USA. Tel.: +1 612-626-0141; fax: +1 612-624-3869. rturesky@umn.edu.

EThe first two authors made equal contributions

Supporting Information

The mass spectra of peptides that are unique to human albumin (Figures S1-S10) are available free of charge via the Internet at http:// pubs.acs.org.
} 


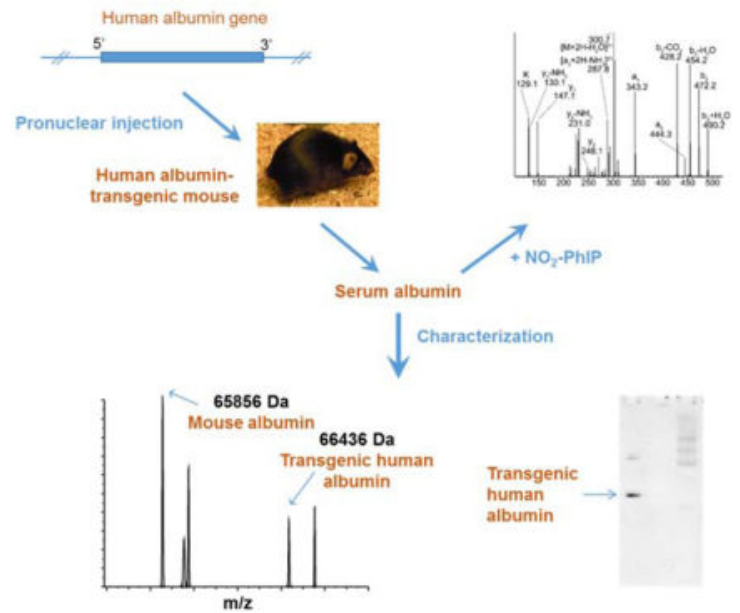

\section{Keywords}

Human serum albumin; transgenic mice; proteomics; carcinogen-albumin adducts; heterocyclic aromatic amines

\section{INTRODUCTION}

Albumin is the most abundant serum protein in humans. ${ }^{1}$ It is synthesized in human liver hepatocytes, initially as a preproalbumin (609 amino acids), and then released from endoplasmic reticulum as a mature protein with 585 amino acids after cleavage of the signal peptide squence. ${ }^{2}$ Albumin is critical in maintaining the colloid osmotic pressure and transporting hormones, fatty acids, and many xenobiotic compounds including therapeutic drugs, environmental pollutants, and chemical carcinogens. ${ }^{1}$ It has been widely used as a target protein for mechanistic studies on the formation of biological adducts with various xenobiotic chemicals and for human risk assessment studies on various carcinogenic compounds. ${ }^{3}$ The reactivity of human albumin has been examined with several classes of carcinogens and electrophiles, which form adducts at various nucleophilic binding sites of albumin. ${ }^{3-5}$ The formation of covalent adducts of carcinogens to proteins such as albumin is thought to be driven not only by the abundance and relative nucleophilicity of the different amino acid residues available for reaction, but also by non-covalent interactions of the reactive metabolite with different receptor regions of proteins, which can influence the sites of carcinogen adduct formation. ${ }^{6}$

The biomonitoring of protein-carcinogen adducts is an alternative approach to the measurement of DNA adducts for assessing human exposure to hazardous chemicals. In contrast to DNA adducts, carcinogen-protein adducts generally do not undergo repair and are expected to have serum stabilities similar to that of the unmodified protein. ${ }^{7,8}$ Therefore, the albumin adducts are expected to accumulate during chronic exposure to genotoxicants. The reactivity of albumin with various chemicals has been examined in rodent models; $3,9,10$ however, differences between the sequences of human and rodent serum albumins can result in formation of different types of adducts or adducts with different peptide sequences. This 
potential species difference has fueled efforts to develop and validate analytical methods for monitoring human protein biomarkers of chemical exposure. In that regard, although it is possible to examine the chemistry of reactivity of human albumin with activated metabolites of xenobiotics in vitro, similar studies are difficult to pursue in vivo because of potential toxicities of the chemicals in humans. As a result, researchers are often confronted with developing analytical methods to measure carcinogen protein adduct biomarkers in humans without knowledge about the extent of metabolism and adduct formation in vivo. Thus, there is a critical need to establish animal models that express human proteins for mechanistic studies with xenobiotics and to facilitate the development and validation of analytical methods to measure protein adduct biomarkers prior to studies in humans.

The heterologous expression of human albumin gene has already been achieved in bacteria, ${ }^{2}$ yeast, ${ }^{11}$ plants, ${ }^{12}$ and mice. ${ }^{13}$ Human albumin has been successfully produced in the mammary glands of female transgenic mice, ${ }^{13,14}$ where it is secreted into the milk at a high concentration (11.9 g albumin/L). ${ }^{15}$ However, transgenic mouse models with systemic expression of human albumin have not yet been reported, although transgenic mouse models expressing human xenobiotic metabolism enzymes have become very useful in human risk assessment for xenobiotic compounds and in drug discovery and development. ${ }^{16-18}$

The goal of this study is to develop transgenic mouse models that express human albumin, which can be used to study and monitor the nature and kinetics of in vivo formation of protein adducts to chemical carcinogens. We currently have developed a human albumin transgenic mouse model using pronuclear injection methods. The expression of human albumin gene, mRNA and protein was confirmed and characterized by genomic polymerase chain reaction (PCR), reverse transcription polymerase chain reaction (RT-PCR), immunoblotting, and ultra-performance liquid chromatography tandem mass spectrometry (UPLC-MS/MS) methods. The ex vivo formation of transgenic human albumin protein adducts with an activated N-oxidized metabolite of 2-amino-1-methyl-6-phenylimidazo[4,5b] pyridine (PhIP), a prototypical carcinogenic heterocyclic aromatic amine (HAA) formed in cooked meat, ${ }^{19}$ was characterized by UPLC-MS/MS methods. The expression of transgenic human albumin in mice along with the identification of transgenic human albumin adducts with carcinogenic compounds (ex vivo) is an important research milestone. The human albumin transgenic mouse model can provide a unique in vivo tool for the assessment of risks of toxicity associated with human exposure to environmental hazardous chemicals and therapeutic drugs, using human albumin as a protein target.

\section{MATERIALS AND METHODS}

\section{Caution}

PhIP is a carcinogen and should be handled in a well-ventilated fume hood with appropriate protective clothing.

\section{Chemicals and Materials}

PhIP was purchased from Toronto Research Chemicals (Ontario, Canada). Trypsin, chymotrypsin, and human and mouse serum albumins were purchased from Sigma-Aldrich 
(St. Louis, MO). All other chemicals were ACS grade and purchased from Sigma-Aldrich, unless stated otherwise. Isolute C18 solid-phase extraction columns (25-mg) were obtained from Biotage (Charlotte, NC). Amicon ultra-centrifugal filter units with a 10,000 Da molecular weight (M.W.) cutoff were from Millipore (Billerica, MA). HiTrap Blue affinity columns were purchased from GE Healthcare Life Sciences (Pittsburg, PA). A Pierce Albumin Depletion Kit was purchased from Thermo Fisher, Rockford, IL. An antigenaffinity-purified, goat anti-human serum albumin antibody, cross-adsorbed to remove crossreactive antibodies against mouse albumin, was purchased from Bethyl Laboratories (Catalog No. A80-229A; Montgomery, TX). A peroxidase-conjugated rabbit anti-goat secondary antibody was purchased from Sigma-Aldrich. RP11-580P21, a human bacterial artificial chromosome (BAC) clone, was obtained from the BACPAC Resource Center at the Children's Hospital Oakland Research Institute (Oakland, CA). A BAC vector purification kit was purchased from Qiagen (Hilden, Germany). TRIzol and SuperScript ${ }^{\circledR}$ III kits were purchased from Thermo Fisher Scientific (Grand Island, NY). The peptide LQQCPF and DNA restriction enzyme XbaI were purchased from New England Biolabs (Ipswich, MA). DNA size markers were purchased from Thermo Fisher Scientific. Protein size markers and nitrocellulose membranes were purchased from Bio-Rad (Hercules, CA). An Amersham ECL immunoblotting detection reagent was purchased from GE Healthcare Life Sciences. All PCR primers were chemically synthesized by Integrated DNA Technologies (Coralville, IA).

\section{Animal Procedures}

All animal experimental procedures were reviewed and approved by the Wadsworth Center Institutional Animal Care and Use Committee. All mice used in this work were obtained from breeding stocks maintained at the Wadsworth Center, and were bred and kept under conditions of controlled temperature $\left(23^{\circ} \mathrm{C}\right)$ and lighting (light 7:00 a.m.-7:00 p.m./dark 7:00 p.m.-7:00 a.m.), with food and water provided ad libitum.

\section{Generation of the Human Serum Albumin Transgenic Mouse Model}

The RP11-580P21 BAC clone (Figure 1A), containing human albumin (NCBI Accession Number: NM_000477.5) and alpha-fetoprotein (NCBI Accession Number: NM_001134.2) genes, was used for generation of human albumin-transgenic mice. Transgenic mice were produced at the Wadsworth Center Transgenic and Knockout Mouse Core Facility. Uncut BAC DNA was microinjected into the pronuclei of fertilized eggs of C57BL/6J mice. Mouse pups were screened via PCR analysis using two independent sets of human albumin-specific PCR primers (set \#1: $5^{\prime}$-agtatattagtgctaatttcc- $3^{\prime}$ and $5^{\prime}$-aggatgatgttcaattatttc- $3^{\prime}$, for a region near the $5^{\prime}$ end of the gene; set \#2: $5^{\prime}$-ccgtccagagattatagtag- $3^{\prime}$ and $5^{\prime}$-atggctctgtgtaccgcatc- $3^{\prime}$, for a region near the $3^{\prime}$ end of the gene) (Figure 1A). Genomic DNA isolated from mouse tail biopsies was used as template. The PCR parameters for amplification of the human albumin transgene were: 38 cycles, each at $94{ }^{\circ} \mathrm{C}$ for $30 \mathrm{~s}, 50{ }^{\circ} \mathrm{C}$ for $30 \mathrm{~s}$, and $72{ }^{\circ} \mathrm{C}$ for $60 \mathrm{~s}$.

\section{RNA Isolation and RNA-PCR Analysis}

Total RNA from various mouse tissue samples was isolated using TRIzol Reagent (Thermo Fisher Scientific). The RNA concentration was determined by measuring absorbance at 260 $\mathrm{nm}$, with RNA quality verified through agarose gel electrophoresis. Reverse transcription 
was carried out using a SuperScript ${ }^{\circledR}$ III kit (Thermo Fisher Scientific). First-strand cDNAs were synthesized with use of random decamer primers. A RNA sample from the liver of an anonymous adult human donor ${ }^{20}$ was used as a positive control. The subsequent PCR analysis was performed using two sets of primers: one set (5'-gagaccagaggttgatgtgatg- $3^{\prime}$ and $5^{\prime}$-cagcagcacgacagagtaat- $3^{\prime}$ ) is unique to human albumin cDNA sequence, producing a 691 bp amplicon; whereas the second set (5'-aagcatgggcagtagctcg- $3^{\prime}$ and $5^{\prime}$ -

aactctttgggaacgtatgtttcatc- $3^{\prime}$ ) amplifies both human and mouse albumin cDNAs. The PCR products ( 871 base pairs, bp) from the second set of primers were further treated with XbaI, which would cut the human albumin amplicon into two pieces (437 bp and $438 \mathrm{bp}$, respectively), while leaving the mouse albumin amplicon intact. A third set of primers (5'accacagtccatgccatcac- $3^{\prime}$ and $5^{\prime}$-caccacctgttgctgtagcc- $3^{\prime}$ ) was employed to detect the transcripts of mouse glyceraldehyde 3-phosphate dehydrogenase (GAPDH) gene, used as a loading control. The PCR parameters for all primer sets were: 38 cycles, each at $94{ }^{\circ} \mathrm{C}$ for $30 \mathrm{~s}, 50{ }^{\circ} \mathrm{C}$ for $30 \mathrm{~s}$, and $72{ }^{\circ} \mathrm{C}$ for $60 \mathrm{~s}$.

\section{Serum Albumin Purification and Immunoblot Analysis}

Serum albumin proteins were purified as described previously; ${ }^{21,22}$ mouse serum $(50 \mu \mathrm{L})$ was diluted with $50 \mathrm{mM}$ potassium phosphate buffer, $\mathrm{pH} 7.4(1 \mathrm{~mL})$, prior to affinity chromatography using HiTrap Blue affinity resin. The concentration of the eluted protein was estimated by measuring UV absorption at $280 \mathrm{~nm} .{ }^{23}$ The purity of the eluted protein was assessed via sodium dodecyl sulfate polyacrylamide gel electrophoresis analysis, with authentic human and mouse serum albumin proteins (Sigma-Aldrich) as controls. Immunoblot analysis was performed as described ${ }^{24}$ with use of a goat anti-human albumin antibody that does not cross-react with mouse albumin (Bethyl Laboratories), at a 1:3,000 dilution. Immunoreactive proteins were visualized with use of an Amersham ECL immunoblotting detection reagent and the luminescent images were recorded by a Gel-Doc imaging system (Bio-Rad).

\section{Serum Albumin Sample Preparation for Mass Spectrometric Analysis}

The purified albumin protein was washed with $100 \mathrm{mM}$ potassium phosphate buffer $(\mathrm{pH}$ 7.5) three times with an Amicon ultracentrifugal filter unit with a 10,000 Da M.W. cutoff (Millipore). Mixed disulfides formed at the $\mathrm{Cys}^{34}$ of human albumin ( $200 \mu \mathrm{g}, 3 \mathrm{nmol}$ in 100 $\mathrm{mM}$ potassium phosphate buffer, $\mathrm{pH}$ 7.4) were removed by treatment with $\beta$ mercaptoethanol ( $\beta$ ME) $\left(210 \mathrm{nmol}\right.$ in $\left.\mathrm{H}_{2} \mathrm{O}\right)$ at $37{ }^{\circ} \mathrm{C}$ for 90 min. ${ }^{21}$ For the $\mathrm{Cys}^{34}$ oxidation experiments, albumin was treated with a 10x molar excess of $m$-chloroperoxybenzonic acid ( $m$-CPBA) as reported. ${ }^{25}$ For other experiments, the albumin was reduced with $25 \mathrm{mM}$ dithiothreitol (DTT) at $22{ }^{\circ} \mathrm{C}$ for $1 \mathrm{~h}$ and derivatized with $75 \mathrm{mM}$ iodoacetamide (IAA) at $55^{\circ} \mathrm{C}$ in the dark for $2 \mathrm{~h}$. Afterwards, excess $\beta \mathrm{ME}$ or IAA was removed through an Amicon ultra-filter unit with a 10,000 Da M.W. cutoff (Millipore) by centrifugation. ${ }^{21}$

\section{Analysis of Reactivity of Albumin with 2-Nitro-1-methyl-6-phenylimidazo[4,5-b]pyridine $\left(\mathrm{NO}_{2}\right.$-PhIP)}

The adduction of the activated $\mathrm{N}$-oxidized derivative of $\mathrm{PhIP}, \mathrm{NO}_{2}$ - $\mathrm{PhIP}$ was previously described. ${ }^{26}$ Reduced albumin (1.5 nmol) was modified with $4.5 \mathrm{nmol}$ of $\mathrm{NO}_{2}-\mathrm{PhIP}$ and $\left[{ }^{2} \mathrm{H}_{5}\right]-\mathrm{NO}_{2}$-PhIP (1:1 molar ratio) in $100 \mathrm{mM}$ potassium phosphate buffer $(\mathrm{pH} 7.4,100 \mu \mathrm{L})$ 
for $16 \mathrm{~h}$ at $37^{\circ} \mathrm{C}$. Transgenic mouse or commercial human plasma $(5 \mu \mathrm{L})$ was diluted with $100 \mu \mathrm{L} 100 \mathrm{mM}$ potassium phosphate buffer, $\mathrm{pH}$ 7.4. The plasma was modified with 4.5 nmol of $\mathrm{NO}_{2}-\mathrm{PhIP}$ and $\left[{ }^{2} \mathrm{H}_{5}\right]-\mathrm{NO}_{2}-\mathrm{PhIP}\left(1: 1\right.$ molar ratio) $\left(2 \mu \mathrm{L}\right.$ in DMSO) for $16 \mathrm{~h}$ at $37{ }^{\circ} \mathrm{C}$. The $\mathrm{NO}_{2}$-PhIP molecules unbound to albumin were removed by solvent extraction with $2 \mathrm{x}$ volume of ethyl acetate, twice. The albumin solution underwent vacuum centrifugation for 5 min to remove the residual ethyl acetate, and the solution was subjected to a buffer exchange (450 $\mu \mathrm{L}$ of $100 \mathrm{mM}$ potassium phosphate buffer, $\mathrm{pH} 7.4,2$ times) to remove residual unbound PhIP using an Amicon ultra-filter unit with a 10,000 Da M.W. cutoff (Millipore). Albumin from modified plasma was purified, prior to proteolytic digestion using a Pierce Albumin Depletion Kit (Thermo Fisher).

\section{Trypsin/Chymotrypsin Digestion}

Prior to digestion, proteins were washed with $50 \mathrm{mM}$ ammonium bicarbonate buffer $(\mathrm{pH}$ 8.5) three times in an Amicon ultracentrifugal filter unit with a 10,000 Da M.W. cutoff (Millipore). The digestion of albumin with trypsin and chymotrypsin was performed as previously described. ${ }^{22}$ In brief, trypsin $(1: 50, \mathrm{w} / \mathrm{w})$ and chymotrypsin $(1: 25, \mathrm{w} / \mathrm{w})$ were added to each sample of $50 \mu \mathrm{g}$ of albumin protein in $200 \mu \mathrm{L}$ of $50 \mathrm{mM}$ ammonium bicarbonate buffer, $\mathrm{pH} 8.5$. The mixture was agitated at $37{ }^{\circ} \mathrm{C}$ for $20 \mathrm{~h}$.

\section{UPLC-MS/MS Analysis of Peptides and Peptide-adducts Derived from Mouse and Human Albumin}

A Dionex Ultimate 3000 LC (Thermo Fisher), an Orbitrap Elite ${ }^{\mathrm{TM}}$ Hybrid Ion Trap-Orbitrap mass spectrometer (Thermo Fisher), and an Advance CaptiveSpray ${ }^{\mathrm{TM}}$ source (Michrom BioResources, Auburn, CA) was used in the current work. Data were acquired by using Xcalibur Qual Browser Software 2.2 (Thermo Fisher).

The tryptic/chymotryptic digests of albumin or albumin adducts were cleaned using offline solid phase extraction, as described previously. ${ }^{21}$ Albumin digests (100 ng in $5 \mu \mathrm{L}$ of $\mathrm{H}_{2} \mathrm{O}$ :DMSO, 1:1) were resolved with a Magic C18AQ column $(0.3 \mathrm{~mm}$ x $150 \mathrm{~mm}$, Michrom BioResources) employing a 25-min linear gradient starting from 100\% solvent A (5\% $\mathrm{CH}_{3} \mathrm{CN}$ in $\mathrm{H}_{2} \mathrm{O}$ containing $\left.0.01 \% \mathrm{HCO}_{2} \mathrm{H}\right)$ to $100 \%$ solvent $\mathrm{B}\left(5 \% \mathrm{H}_{2} \mathrm{O}\right.$ in $\mathrm{CH}_{3} \mathrm{CN}$ containing $0.01 \% \mathrm{HCO}_{2} \mathrm{H}$ ) at a flow rate of $5 \mu \mathrm{L} / \mathrm{min}$. The tuning parameters for the MS were previously reported..$^{21}$ The capillary temperature was set at $270{ }^{\circ} \mathrm{C}$; ionization voltage, $2 \mathrm{kV}$ in positive ion mode; ion trap mass spectrometry (ITMS) acquired with $1 \mu$ scan; maximum injection time, $10 \mathrm{~ms}$; activation time, $10 \mathrm{~ms}$; activation Q, 0.35; AGC (automated gain control), 30000. Peptide adducts were identified manually, facilitated by using MyriMatch 2.1.140 software that was developed by Dr. David Tabb at Vanderbilt University. ${ }^{21,27}$ For the data dependent scanning experiments, a full MS scan (100 - 1800 $\mathrm{m} / \mathrm{z}$ ) was obtained, followed by five data dependent scans $(100-1800 \mathrm{~m} / \mathrm{z})$. Identification of peptides and sequence coverage were facilitated by MyriMatch using a 32-protein subset database containing mouse and human albumin peptide sequences. ${ }^{27}$ All parameters were set up with default values: precursor ion mass tolerance, $1.25 \mathrm{~m} / \mathrm{Z}$, fragment ion mass tolerance, $0.5 \mathrm{~m} / \mathrm{z}$, false positive identification rate, $1 \%$; dynamic modification: carbamidomethyl of cysteines (+57.02 Da), oxidation on methionines (+15.99 Da) and deamidation of N-terminal glutamines $(-17.03 \mathrm{Da})$. 


\section{UPLC-MS Characterization of Intact Albumin from Transgenic Mouse Plasma}

Intact, non-digested albumin proteins (50 ng in $1 \mu \mathrm{L}$ of 20\% DMSO) were separated with an Agilent ZORBAX 300SB-C 3 column $(3.5 \mu \mathrm{m}, 300 \AA ̊, 100$ x $0.3 \mathrm{~mm}$; Agilent Technologies, Mississauga, ON, Canada) employing a 25-min linear gradient of $95 \%$ solvent A (5\% $\mathrm{CH}_{3} \mathrm{CN}$ in $\mathrm{H}_{2} \mathrm{O}$ containing $\left.0.01 \% \mathrm{HCO}_{2} \mathrm{H}\right)$ to $50 \%$ solvent $\mathrm{B}\left(5 \% \mathrm{H}_{2} \mathrm{O}\right.$ in $\mathrm{CH}_{3} \mathrm{CN}$ containing $0.01 \% \mathrm{HCO}_{2} \mathrm{H}$ ) at a flow rate of $5 \mu \mathrm{L} / \mathrm{min}$. Data were acquired with an Orbitrap Elite $^{\mathrm{TM}}$ Hybrid Ion Trap-Orbitrap mass spectrometer using an Advance CaptiveSpray ${ }^{\mathrm{TM}}$ source (Michrom BioResources). The capillary temperature was set at $270{ }^{\circ} \mathrm{C}$; ionization voltage, $3.5 \mathrm{kV}$ in positive ion mode; Fourier transform mass spectrometry (FTMS) acquired with $25 \mu$ scans; maximum injection time, $50 \mathrm{~ms}$; resolution, 15000. Automated gain control was set $10^{6}$ for FTMS. The pressure $(\Delta \mathrm{p})$ in the HCD cell was decreased to $\sim 1 \times 10^{-11}$ Torr for improved mass resolution of proteins. A spectrum of 25 scans across the peak of human or mouse albumin was created for protein deconvolution experiments employing Protein Deconvolution Software 4.0 (Thermo Fisher). The software parameters were as follows: deconvolution algorithm, unresolved (ReSpect); noise rejection, 95\% confidence; chromatogram $\mathrm{m} / \mathrm{z}$ range, $1000-2000 \mathrm{Da}$; output mass range, $60000-70000 \mathrm{Da}$; mass tolerance, $0.5 \mathrm{Da}$; charge state range, $10-100$; resolution, 15000 at $\mathrm{m} / \mathrm{z} 400$.

\section{RESULTS}

\section{Generation and Characterization of Human Albumin Transgenic Mice}

The human albumin transgene-injected mouse embryos gave rise to a total of 123 pups, three of which, one male and two females, were found via genomic PCR screening to harbor the human albumin transgene (Figure 1B). The three founder (F0) mice mated with wild-type C57BL/6J mice, generating F1 hemizygotes. The latter mated with wild-type C57BL/6J mice also, generating F2 hemizygotes. The F1 and F2 pups were used for initial characterization of fertility, growth rates, and stability of transgene transmission. The transgene was carried by both male and female pups, indicating that it was not located on the $\mathrm{Y}$ chromosome. Of all F2 pups derived from " $\mathrm{F} 1$ hemizygotes $\mathrm{x}$ wild-type" matings, 38$60 \%$ were positive for the transgene; these ratios were close to the $50 \%$ value predicted by the Mendelian inheritance patterns and indicated absence of obvious embryonic lethality or transgene instability. The transgenic pups appeared to have normal fertility, and no obvious biological or behavioral deficiencies were observed. There was no statistically significant difference in body weights between transgene positive and negative littermates at weaning (data not shown). All data on transgene expression and transgenic human albumin characterization presented in this manuscript were obtained using transgenic lines 1 and 2 .

\section{Expression of Human Albumin Transcripts in Human Albumin Transgenic Mice}

The presence of transgenic human albumin transcripts in the transgenic mouse liver was confirmed by RT-PCR analysis (Figure 2A) with a set of human albumin-specific primers. Specificity of the PCR primers was confirmed by the detection of the same PCR product in a positive control RNA sample from a human liver tissue specimen, and by the non-detection of any positive signal in a negative control liver RNA sample of wild-type mice. Identity of the positive RT-PCR product of human albumin cDNA from the transgenic mouse liver was further confirmed by DNA sequencing (data not shown). Expression of transgenic human 
albumin RNA in major organs, including liver, lung, heart, intestine, kidney, skeletal muscle, and brain, of the transgenic mice was also examined by RT-PCR analyses. The human albumin transcript was detected only in liver (Figure 2B), a result confirming that expression of the transgene in mice maintained the liver specificity that is known for the native albumin gene expression in humans and mice. ${ }^{28,29}$ As a control, transcripts of mouse GAPDH, a house-keeping gene, were detected in all tissues analyzed.

In order to estimate the abundance of transgenic human albumin transcripts relative to that of endogenous mouse albumin transcripts in the transgenic mouse liver, RT-PCR analysis was also carried out with a set of primers that are able to amplify both human and mouse albumin cDNAs (Figure 2C and 2D). The RT-PCR products were subjected to restriction digestion with $\mathrm{Xba}$ I, which cuts the human, but not the mouse, albumin amplicons into two fragments of nearly identical lengths (Figure 2C). A comparison of the relative intensities of the upper and lower bands, representing the mouse and human albumin amplicons, respectively, in serially diluted samples of PCR products (Fig. 2D) suggested that the human albumin transcript was expressed at lower levels than that of the endogenous mouse albumin transcript.

\section{Immunochemical Detection and Quantification of Human Albumin Protein in Transgenic Mouse Plasma}

The presence of transgenic human albumin protein was demonstrated via immunoblot analyses (Figure 3) using an anti-human albumin antibody. The antibody detected a positive band in samples of purified total serum albumin of the human albumin-transgenic mice; this positive band had the same size as that of a human albumin standard and it was not detected in samples of purified serum albumin of wild-type female mice (Figure 3A). A comparison of the band intensity of transgenic human albumin in the transgenic mice to the band intensity of serially diluted human albumin standards suggested an abundance of $\sim 6 \mathrm{ng}$ of human albumin was much smaller than that of mouse albumin in $30 \mathrm{ng}(\sim 20 \%)$ of total albumin purified from the transgenic mouse serum. In further studies, transgenic human albumin protein was detected in the serum of both male and female transgenic mice, at ages of 7 days, 14 days, and 3-5 months (Figure 3B). These results indicate that the transgenic human albumin, which was apparently at full-length, was synthesized in the liver and secreted to the serum of the transgenic mice.

\section{Targeted UPLC-MS/MS Characterization of Albumin in Transgenic Mouse Plasma}

Mature human and mouse albumins share $72 \%$ amino acid homology (Figure 4). A sequence coverage of $25 \%$ and $74 \%$ was obtained, respectively, for human and mouse albumin by data dependent scanning mass spectrometry of the tryptic/chymotryptic digest of transgenic human albumin co-purified with native mouse albumin from the transgenic mouse serum. Eighteen peptides were identified, of which eleven peptides were unique to the human albumin sequence, and the sequence coverage by twelve identified peptides was $17 \%$ (Table 1; Figure 4). These peptides are distributed across all three homologous domains of human serum albumin (Table 1). ${ }^{1}$ The mass chromatograms and product ion spectra of two representative peptides of transgenic human and mouse albumin recovered following digestion of the purified serum protein with trypsin and chymotrypsin are discussed below. 
The mass spectra of the peptides unique to human albumin are shown in Figures 5 and 7 and Supplemental Figures S1 - S10.

The peptide ${ }^{234}$ LATDLTK $^{240}\left([\mathrm{M}+2 \mathrm{H}]^{2+}\right.$ at $\left.\mathrm{m} / \mathrm{z} 381.2\right)$, which is unique to mouse albumin, was detected in both wild-type and transgenic mice (Figures 5A and 5B). The homologous sequence in humans is ${ }^{234} \operatorname{LVTDLTK}^{240}\left([\mathrm{M}+2 \mathrm{H}]^{2+}\right.$ at $\left.\mathrm{m} / \mathrm{z} 395.2\right)$, which was detected by targeted scanning in the albumin purified from the transgenic mouse serum, but not detected in the wild-type mouse serum (Figures 5D and 5E). The product-ion spectra of ${ }^{234}$ LATDLTK $^{240}$ and ${ }^{234}$ LVTDLTK $^{240}$ are shown in Figures $5 \mathrm{C}$ and 5F, respectively. The relative signal intensity of ion counts of human ${ }^{234}$ LVTDLTK $^{240}$ to mouse ${ }^{234}$ LATDLTK $^{240}$ was $\sim 15 \%$ in the transgenic mouse plasma (Figure 6 ).

The $\mathrm{Cys}^{34}$ residues of both human and mouse albumins are highly nucleophilic sites that adduct to electrophiles. ${ }^{3,8}$ The peptide sequence containing the $\mathrm{Cys}^{34}$ residue of human albumin, ${ }^{31} \mathrm{LQQC}{ }^{*}[\mathrm{IAA}] \mathrm{PF}^{36}$, was detected in the samples of transgenic mice only by targeted UPLC-MS/MS (Figures 7A and 7B). The missed-cleaved hexapeptide, ${ }^{31} \mathrm{LQKC}{ }^{*}[\mathrm{IAA}] \mathrm{SY}^{36}$, which is unique to mouse albumin, was identified in both wild-type and transgenic mice, by targeted and data-dependent scanning mass spectrometry (Figures 7D and 7E). The corresponding mass spectra are shown in Figure 7F. The relative abundance of ${ }^{31} \mathrm{LQKC}{ }^{*}[\mathrm{IAA}] \mathrm{SY}^{36}$ was $3 \mathrm{x}$ greater than that of ${ }^{31} \mathrm{LQQC}^{*}{ }^{[\mathrm{IAA}]} \mathrm{PF}^{36}$ in albumin purified from transgenic mouse serum (Figure 7B vs. Figure 7E). We further characterized the sequence surrounding the $\mathrm{Cys}^{34}$ following oxidation of albumin with $m$-CPBA to form cysteine sulfonic acid $\left[\mathrm{Cys}{ }^{\mathrm{SO} 3 \mathrm{H}}\right]$. The single missed-cleavage peptide ${ }^{31}{ }^{2 Q Q C}{ }^{*}[\mathrm{SO} 3 \mathrm{H}]$ PFEDHVK ${ }^{41}$ of human albumin was recovered following proteolytic digestion with trypsin/chymotrypsin. ${ }^{25}{ }^{31} \mathrm{LQQC}^{*}[\mathrm{SO} 3 \mathrm{H}] \mathrm{PFEDHVK}{ }^{41}$ was identified in the albumin samples of transgenic mice but not wild-type mice (Figure S1). The mass spectrum of ${ }^{31} \mathrm{LQQC}^{*}[\mathrm{SO} 3 \mathrm{H}] \mathrm{PFEDHVK}^{41}$ is in agreement with our previous study (Figure S-1C). ${ }^{25}$ The relative level of ion counts of ${ }^{31} \mathrm{LQQC}^{*}[\mathrm{SO} 3 \mathrm{H}] \mathrm{PFEDHVK}^{41}$ in the transgenic albumin sample is $\sim 6 \%$ of the level observed for an equal amount of commercial human albumin digest assayed by UPLC-MS/MS (data not shown).

\section{UPLC-MS Analysis of Full-length Mouse and Human Albumin Co-expressed in Transgenic Mice Plasma}

The mass chromatograms of the wild-type and transgenic albumin samples are shown in Figure 8A. The top three ions of the albumin proteins for human $\left([\mathrm{M}+47 \mathrm{H}]^{47+}\right.$ at $\mathrm{m} / \mathrm{z}$ 1414.6; $[\mathrm{M}+46 \mathrm{H}]^{46+}$ at $\mathrm{m} / \mathrm{z} 1445.3 ;[\mathrm{M}+44 \mathrm{H}]^{44+}$ at $\left.\mathrm{m} / \mathrm{z} 1510.9\right)$ and mouse $\left([\mathrm{M}+47 \mathrm{H}]^{47+}\right.$ at $\mathrm{m} / \mathrm{z} 1402.2 ;[\mathrm{M}+46 \mathrm{H}]^{46+}$ at $\mathrm{m} / \mathrm{z} 1432.6 ;[\mathrm{M}+44 \mathrm{H}]^{44+}$ at $\mathrm{m} / \mathrm{z}$ 1497.7) were selected based on the full scan mass spectra of standard human and mouse serum albumin samples. The peak attributed to transgenic human albumin was not detected in the albumin from wild-type mice (Figure 8A), but it was present in the albumin from transgenic mice (Figure 8B). The peak area obtained from the mass chromatograms of the top three ions for human and mouse albumin show that the relative abundance of human albumin in the transgenic mouse serum was $\sim 19 \%$ of that of endogenous mouse albumin (Figure $8 \mathrm{~B}$ ). The full scan mass spectra for the human and mouse albumin of transgenic mice and the proposed ion charge states are shown in Figure 8C. We determined whether the human albumin in the transgenic mouse 
serum was a full-length or truncated protein by mass spectral deconvolution analysis. The signals of human albumin were not seen in the spectrum of wild-type mice (Figure 8D). Molecular weights (M.W.), 65,856 Da (vs. calculated M.W. 65,858 Da) ${ }^{30}$ and 65,974 Da, of reduced and cysteinylated mouse albumin proteins, respectively, were shown in the deconvoluted spectral data of transgenic and wild-type mice (Figures 8D and 8E). The deconvoluted spectral data (Figure 8E) show molecular weights $66,436 \mathrm{Da}$ (vs. calculated M.W. 66,437 Da) and 66,555 Da, for the unmodified and cysteinylated human albumin, respectively. The observed masses are in agreement with reported M.W. for human albumin $(66,436 \mathrm{Da}){ }^{1,31,32}$ The deconvolution of the spectral data of $\beta$ ME-treated standard human albumin displays molecular weights of 66,436 $\mathrm{Da}$ and 66597, for the unmodified and glycosylated human albumin (+161 Da), respectively (Figure 8F). ${ }^{31,32}$

\section{Targeted UPLC-MS/MS Analysis of Albumin Adducts Formed with $\mathrm{NO}_{2}-\mathrm{PhIP}: \mathrm{NO}_{2}-\left[{ }^{2} \mathrm{H}_{5}\right]-$ PhIP in Transgenic Mouse Plasma ex vivo}

Both human and mouse albumin proteins contain the nucleophilic $\mathrm{Cys}^{34}$ and $\mathrm{Tyr}^{411}$ residues. In silico analysis predicts recovery of ${ }^{31} \mathrm{LQQCPF}^{36}$ and ${ }^{411} \mathrm{YTK}^{413}$ peptides from tryptic/chymotryptic digestion for human albumin, and ${ }^{34} \mathrm{CSY}^{36}$ and ${ }^{411} \mathrm{YTQK}^{414}$ for mouse albumin. The transgenic serum albumin samples were treated with a 1:1 ratio of $\mathrm{NO}_{2}$ $\mathrm{PhIP}: \mathrm{NO}_{2}-\left[{ }^{2} \mathrm{H}_{5}\right]-\mathrm{PhIP}$ as previously reported. ${ }^{22}$ The human tripeptide sequence containing the adduct of $\mathrm{NO}_{2}-\mathrm{PhIP},{ }^{411} \mathrm{Y}^{*}\left[\right.$ desaminoPhIP] $\mathrm{TK}^{413}$, was not detected in albumin purified from wild-type mouse (Figure 9A), but it was detected in albumin from transgenic mouse (Figure 9B). The mass spectrum of ${ }^{411} \mathrm{Y}^{*}\left[\right.$ desaminoPhIP] $\mathrm{TK}^{413}$ (Figure 9C) is in agreement with the spectrum previously reported. ${ }^{21,22}$ In contrast, an adduct of $\mathrm{NO}_{2}$-PhIP was identified at ${ }^{411} \mathrm{Y}^{*}[$ desaminoPhIP $] \mathrm{TQK}^{414}$ in mouse albumin of both transgenic and wild-type mice (Figures 9D and 9E). The reconstructed ion mass chromatogram of $\mathrm{NO}_{2}-\mathrm{PhIP}$ adducted mouse peptide ${ }^{411} \mathrm{Y}^{*}$ [desaminoPhIP] $\mathrm{TQK}^{414}$ and its corresponding mass spectrum are shown in Figures 9D-9F. The relative level of ion counts of ${ }^{411} \mathrm{Y}^{*}[$ desaminoPhIP $] \mathrm{TK}^{413}$ from transgenic human albumin to the ion counts of ${ }^{411} \mathrm{Y}^{*}\left[\right.$ desaminoPhIP] $\mathrm{TQK}^{414}$ from endogenous mouse albumin was very low $(\sim 0.1 \%)$ in transgenic mice (Figure 9B vs. Figure 9E).

An adduct of $\mathrm{NO}_{2}$-PhIP was formed at $\mathrm{Cys}^{34}$ of ${ }^{31} \mathrm{LQQC} *$ [desaminoPhIP] $\mathrm{PF}^{36}$ in human albumin of transgenic mice (Figure 10); however, we did not see this adduct formed at $\mathrm{Cys}^{34}$ of mouse albumin, at ${ }^{34} \mathrm{C}^{*}\left[\right.$ desaminoPhIP] $\mathrm{SY}^{36}$, the single tryptic missedcleaved ${ }^{31}{ }^{\mathrm{LQKC}}{ }^{*}\left[\right.$ desaminoPhIP] $\mathrm{SY}^{36}$ or tryptic/chymotryptic missedcleaved ${ }^{31}{ }^{3 Q} \mathrm{QKC}^{*}\left[{ }^{[\text {desaminoPhIP] }} \mathrm{SYDEHAK}^{41}\right.$. The relative signal of ion counts of human ${ }^{31} \mathrm{LQQC}^{*}\left[\right.$ desaminoPhIP] $\mathrm{PF}^{36}$ to mouse ${ }^{411} \mathrm{Y}^{*}$ [desaminoPhIP] ${ }^{2} \mathrm{CK}^{414}$ in transgenic mice was $\sim 2 \%$ (Figure 10B vs Figure 9E). The product ion spectra of the $\mathrm{NO}_{2}-\left[{ }^{2} \mathrm{H}_{5}\right]-\mathrm{PhIP}$ peptide adducts also displayed the same pattern of fragmentation with a shift of $m / z 5$ as was seen in previous studies (unpublished results, Yi Wang).

The effects of the mouse plasma matrix and, particularly, the large excess of mouse albumin on the reactivity of $\mathrm{NO}_{2}$ - $\mathrm{PhIP}$ to transgenic human albumin were examined by targeted UPLC-MS/MS analysis. The relative reactivities of human albumin expressed in transgenic mouse plasma and commercial human plasma to bind $\mathrm{NO}_{2}-\mathrm{PhIP}$ were estimated by comparing the levels of two human albumin peptide $\mathrm{NO}_{2}-\mathrm{PhIP}$ 
adduct, ${ }^{31}{ }^{\mathrm{LQQQ}}{ }^{*}$ [desaminoPhIP] $\mathrm{PF}^{36}$ and ${ }^{411} \mathrm{Y}^{*}\left[\right.$ desaminoPhIP] ${ } \mathrm{TK}^{413}$ (Figures 11 and 12). The relative amount of ${ }^{411} \mathrm{Y}^{*}[$ desaminoPhIP $] \mathrm{TQK}^{414}$, the homologous mouse albumin peptide adduct with $\mathrm{NO}_{2}$-PhIP that was only formed in transgenic mouse plasma (Figure 11D) but not in human plasma (Figure 11C).

The mass spectra of ${ }^{411} \mathrm{Y}^{*}[$ desaminoPhIP $] \mathrm{TK}^{413}$ and ${ }^{411} \mathrm{Y}^{*}[$ desaminoPhIP $] \mathrm{TQK}^{414}$ formed in transgenic mouse plasma (Figure 11) are in agreement with those formed in purified albumin protein solution (Figure 9 and unpublished results). The relative signal intensity of human ${ }^{411} \mathrm{Y}^{*}$ [desaminoPhIP] $\mathrm{TK}^{413}$ formed in transgenic mouse plasma is $\sim 1 \%$ of the signal intensity of mouse ${ }^{411} \mathrm{Y}^{*}\left[\right.$ desaminoPhIP] $\mathrm{TQK}^{414}$, extracted from both $\mathrm{NO}_{2}$-PhIP-pretreated whole transgenic mouse plasma (Figure 11) and purified transgenic human albumin solution (Figure 9). The efficiencies of mouse ${ }^{411} \mathrm{Y}^{*}[$ desaminoPhIP $] \mathrm{TQK}^{414}$ formation in wild-type and transgenic mouse plasma were comparable with a ratio of ion counts of $\sim 1: 1.07$ (Figure 9D vs. Figure $9 \mathrm{E}$ ). The relative signal intensity of ${ }^{411} \mathrm{Y}^{*}\left[\right.$ desaminoPhIP] $\mathrm{TK}^{413}$ of transgenic mouse plasma is $\sim 3 \%$ of that of commercial human plasma (Figure 11).

Human ${ }^{31} \mathrm{LQQC}^{*}\left[\right.$ desaminoPhIP] $\mathrm{PF}^{36}$ was also formed and detected in both commercial human and transgenic mouse plasma (Figure 12). The relative signal of ion counts of ${ }^{31} \mathrm{LQQC}^{*}$ [desaminoPhIP] $\mathrm{PF}^{36}$ of transgenic mouse plasma is $~ 2 \%$ of that of commercial human plasma (Figure 12). LC-MS deconvolution suggest that the ratio of full-length human and mouse albumins in the transgenic mouse plasma used for these experiments were about $15 \%$, which agree with immunochemistry (Figures 8 , and unpublished results).

\section{DISCUSSSION}

Expression of recombinant human albumin in transgenic mice offers an alternative way to study the reactivity of human albumin with xenobiotic chemicals and endogenous genotoxicants with animal experiments. Controlled and dose-response studies of potentially hazardous chemicals can be performed in transgenic mice that could never be performed in humans. Such studies would also greatly advance the development of analytical methods to measure albumin carcinogen adducts and lead to suitable animal models for in vivo quantitative human risk or safety assessment to environmental hazardous chemicals and therapeutic drugs. Expression of human albumin has been achieved in transgenic bacterial, ${ }^{2}$ yeast, ${ }^{11}$ plant ${ }^{12}$ and selectively in the mammary gland of mice. ${ }^{13}$ The heterologous expression of human albumin was reported to be high in transgenic rice seeds, in which the expression of human albumin was characterized by immunoblotting, x-ray crystallography, and peptide mapping methods. ${ }^{33}$ An important factor that affects the albumin expression level is the protein stability. For control wild-type mice, the half-life of mouse albumin has been estimated at 1-2 days. ${ }^{8}$ To date, the stability of human albumin in our transgenic mouse model has not yet been determined.

We have confirmed the expression of human albumin in the plasma of a newly established human albumin transgenic mouse model by genomic and proteomic techniques.

Immunochemistry blotting and UPLC-MS analyses show that the transgenic human albumin was a full-length mature protein. The sequence coverages of tryptic/chymotryptic digests of mouse albumin and commercial human albumin exceed $75 \%$ when analyzed by the data dependent scanning mass spectrometry. ${ }^{25}$ We identified twelve peptides (Table 1) unique to 
human albumin that covers $17 \%$ of the transgenic human albumin peptide sequence. These peptides are found across domains I, II, and III of the protein (Table 1). The decreased sequence coverage of the transgenic human albumin is attributed to the co-purified native mouse albumin, which coexisted in more than 5-fold excess and shared $72 \%$ similarity in amino acid sequences with the transgenic human protein.

Human albumin contains one reduced cysteine, $\mathrm{Cys}^{34,1}$ which exists primarily as the thiolate form at physiological $\mathrm{pH}$ due to its low pKa value ( 6.7). ${ }^{34}$ This amino acid residue of albumin is a major site of adduction with electrophiles. ${ }^{3}$ Thus, it was critical to show that the peptide sequence containing this amino acid was present in the albumin transgenic mouse model. The identification of the peptide sequence containing $\mathrm{Cys}^{34}$ of human albumin was confirmed by alkylation of purified transgenic mouse albumin, by IAA, prior to digestion with trypsin/chymotrypsin. The peptides ${ }^{31} \mathrm{LQQC}^{*}{ }^{[\mathrm{IAA}]} \mathrm{PF}^{36}$ and ${ }^{31}{ }^{31} \mathrm{Q} \mathrm{KC}^{*}{ }^{*}[\mathrm{IAA}] \mathrm{SY}^{36}$, which are unique to human and mouse albumin, respectively, were identified in transgenic mouse serum by targeted UPLC-MS/MS. Previous literature showed that the $\mathrm{Cys}^{34}$ of human albumin could be oxidized to cysteine sulfonic acid with excess of $m$-CBPA, and ${ }^{31} \mathrm{LQQC}{ }^{*}[\mathrm{SO} 3 \mathrm{H}] \mathrm{PFEDHVK}^{41}$ was the major peptide recovered after protein digestion with trypsin/chymotrypsin. ${ }^{25}$ By using a similar approach, we identified ${ }^{31} \mathrm{LQQC}^{*}{ }^{* \mathrm{SO} 3 \mathrm{H}]} \mathrm{PFEDHVK}^{41}$ in albumin purified from the serum of transgenic mice.

Our mass spectrometric characterization of human albumin also showed adducts formed at Cys ${ }^{34}$ with the reactive $\mathrm{N}$-oxidized metabolite $\mathrm{NO}_{2}-\mathrm{PhIP}$, data which have been described previously. ${ }^{21,22,26,35}$ The adducted peptides ${ }^{31} \mathrm{LQQC}^{*[\text { desaminoPhIP] }} \mathrm{PF}^{36}$ and ${ }^{411} \mathrm{Y}^{*}[$ desaminoPhIP $] \mathrm{TK}^{413}$, resulted from the ex vivo treatment of transgenic human albumin with $\mathrm{NO}_{2}-\mathrm{PhIP}$, were detected. The desamino adduct of $\mathrm{NO}_{2}-\mathrm{PhIP}$ was also identified at ${ }^{411} \mathrm{Y}^{*}\left[\right.$ desaminoPhIP] $\mathrm{QTK}^{414}$ - of mouse albumin; however, the formation of the $\mathrm{NO}_{2}$-PhIP adduct at the $\mathrm{Cys}^{34}$ of mouse albumin was not detected. In contrast, recent studies showed that reactive quinoneimine metabolite of acetaminophen did form an adduct at Cys ${ }^{34}$ in rat and mouse albumins. ${ }^{36,37}$ The differences in reactivity of $\mathrm{Cys}^{34}$ of human and rodent albumin with some electrophiles reinforce the importance of the transgenic human albumin animal model as an in vivo tool for the assessment of risks of toxicity associated with human carcinogens. The data dependent scanning and targeted UPLC-MS/MS data show that the reactivity of the transgenic human albumin is similar to a commercial human albumin for adduct formation with $\mathrm{NO}_{2}$-PhIP. ${ }^{21}$

The estimated abundance of transgenic human albumin in the model mouse serum varied with different analytical methods. The lack of internal standards is one of the factors that define the limits of quantification of MS measurements. We assumed the efficacy of proteolytic hydrolysis and the ionization of peptides for human and mouse albumin proteins were the same; however, in fact, the ionization efficiencies of peptides can vary greatly. ${ }^{38}$ In the current studies, when human and mouse orthologous peptides, ${ }^{234}{ }^{\text {LVTDLTK }}{ }^{240}$ and ${ }^{234}$ LATDLTK $^{240}$, were assayed, the relative signal of the top 2 most abundant ions of the human peptide was $\sim 15 \%$ of that of the mouse peptide for samples from the transgenic mouse. MS deconvolution data showed that the unmodified and cysteinylated human albumin proteins were both present in the serum albumin of the transgenic mouse, and the 
M.W. of deconvoluted human albumin was in excellent agreement with previous studies (observed M.W. 66,436 Da vs. calculated M.W. 66,437 Da). ${ }^{31}$ Commercial mouse and human albumins were used as positive controls. The HPLC-MS measurement of intact commercial human albumin has been reported previously. ${ }^{31,39}$ LC-MS deconvolution from the current study suggest that the ratio of full-length human to mouse albumin proteins in the transgenic mouse plasma used for these experiments were about 20\%, which is in good agreement to those values obtained by immunochemistry analysis for transgenic human albumin protein, and appear to be most representative of the relative abundance of the two proteins in the serum of the transgenic mice.

The effects of the mouse plasma matrix and the large excess of mouse albumin on the reactivity of $\mathrm{NO}_{2}$-PhIP to the transgenic human albumin protein were examined. The mouse albumin was present in a $\sim 5$-fold excess than the transgenic human albumin in the plasma. We compared the levels of two human albumin peptide adducts with $\mathrm{NO}_{2}-\mathrm{PhIP}$ in transgenic mouse plasma and human plasma. The amount of human albumin peptide adducts with NO2-PhIP formed in transgenic mouse plasma is $2-3 \%$ of the amount of the same adducts formed in commercial human plasma. The ratio of the human albumin peptide $\mathrm{NO}_{2}-\mathrm{PhIP}$ adducts to the orthologous mouse albumin peptide $\mathrm{NO}_{2}-\mathrm{PhIP}$ adducts in transgenic mouse plasma is $\sim 1 \%$. In contrast, the amount of intact human albumin protein to its mouse albumin counterpart co-expressed in these transgenic plasma samples was $\sim 15 \%$ based on LC-MS deconvolution and immunochemistry analyses. The ${ }^{411} \mathrm{Y}^{*}\left[\right.$ desaminoPhIP] $\mathrm{QTK}^{414}$ of mouse albumin appears to be a far more reactive nucleophilic site for adduction of $\mathrm{NO}_{2}$ $\mathrm{PhIP}$ than ${ }^{411} \mathrm{Y}^{*}\left[\right.$ desaminoPhIP] $\mathrm{TK}^{413}$ of human albumin, assuming similar digestion efficiency, recovery and electrospray ionization efficiencies of these homologous peptide adducts. The levels of mouse ${ }^{411} \mathrm{Y}^{*}\left[\right.$ desaminoPhIP] $\mathrm{TQK}^{414}$ formation in wild-type and transgenic mouse plasma are similar (1:1.07). The relative levels of ${ }^{31} \mathrm{LQQC}^{*}\left[\right.$ desaminoPhIP] $\mathrm{PF}^{36}$ and ${ }^{411} \mathrm{Y}^{*}$ [desaminoPhIP] $\mathrm{TK}^{413}$ in transgenic mouse plasma were both lower than those formed in commercial human plasma containing comparable amounts of albumin. Thus, the diminished binding is largely due to the vast excess of competing mouse albumin in the transgenic plasma, but also different constituents in mouse or human plasma are likely bound to the albumins and affect intrinsic reactivities of the proteins with electrophiles. ${ }^{1}$

The analytical methods employed are semi-quantitative and the animal zygosity is not addressed in this report. A higher level of human albumin expression is expected in homozygous transgenic mice, which would make it easier for characterization and quantification of human albumin adducts that are formed in vivo. While the coexistence of the mouse and human albumins in the transgenic mice allows simultaneous study of the reactivities of mouse and human albumins with xenobiotic chemicals and their metabolites, the employment of the transgenic human albumin for in vivo studies is currently not optimal because the endogenous mouse albumin predominates and our goal is to understand the reactivities of genotoxicants with human albumin. It would be advantageous to also develop mouse models in which only the human albumin gene is produced. The current animal model and the associate biochemical and mass spectral data, however, provide important mile stone data. Efforts to generate more "humanized" mouse models, which would allow us 
to conduct the proposed studies in vivo not only for PhIP but also for a larger range of chemical compounds of interest, are underway.

\section{Supplementary Material}

Refer to Web version on PubMed Central for supplementary material.

\section{Acknowledgments}

Funding Sources

This research was supported by NIH Grants R01CA122320 and National Cancer Institute Cancer Center Support grant no. CA077598 (R.J.T.), and R01CA092596 and R01ES020867 (X.D.)

We want to thank Dr. Peter Villalta at University of Minnesota for the help on the Thermo Orbitrap Elite. We also would like to thank the Dr. David Tabb Laboratory at the Department of Biomedical Informatics, and the

Department of Biochemistry and Mass Spectrometry Research Center, Vanderbilt University, for the introduction to and use of the MyriMatch software program.

\section{ABBREVIATIONS}

$\begin{array}{ll}\text { PhIP } & \text { 2-Amino-1-methyl-6-phenylimidazo }[4,5-b] \text { pyridine } \\ \boldsymbol{m} \text {-CPBA } & \text { m-chloroperoxybenzonic acid } \\ \text { DMSO } & \text { dimethyl sulfoxide } \\ \text { DTT } & \text { dithioreitol } \\ \text { GAPDH } & \text { glyceraldehyde 3-phosphate dehydrogenase } \\ \text { HAA } & \text { heterocyclic aromatic amine } \\ \text { IAA } & \text { iodoacetamide } \\ \beta \text { ME } & \beta \text {-mecapthoethanol } \\ \text { NO2-PhIP } & \text { 2-nitro-1-methyl-6-phenylimidazo[4,5- } b] \text { pyridine } \\ \text { PCR } & \text { polymerase chain reaction } \\ \text { RT-PCR } & \text { reverse transcription polymerase chain reaction } \\ \text { SPE } & \text { solid phase extraction } \\ \text { UPLC-MS } & \text { ultra-performance liquid chromatography tandem mass spectrometry }\end{array}$

\section{References}

1. Peters T Jr. Serum albumin. Adv Protein Chem. 1985; 37:161-245. [PubMed: 3904348]

2. Latta M, Knapp M, Sarmientos P, Brefort G, Becquart J, Guerrier L, Jung G, Mayaux JF. Synthesis and purification of mature human serum albumin from E. Coli. Nat Biotech. 1987; 5:1309-1314.

3. Rappaport SM, Li H, Grigoryan H, Funk WE, Williams ER. Adductomics: Characterizing exposures to reactive electrophiles. Toxicol Lett. 2012; 213:83-90. [PubMed: 21501670]

4. Skipper PL, Peng X, SooHoo CK, Tannenbaum SR. Protein adducts as biomarkers of human carcinogen exposure. Drug Metab Rev. 1994; 26:111-124. [PubMed: 8082561] 
5. Turesky RJ, Le Marchand L. Metabolism and biomarkers of heterocyclic aromatic amines in molecular epidemiology studies: lessons learned from aromatic amines. Chem Res Toxicol. 2011; 24:1169-1214. [PubMed: 21688801]

6. Skipper PL. Influence of tertiary structure on nucleophilic substitution reactions of proteins. Chem Res Toxicol. 1996; 9:918-923. [PubMed: 8870977]

7. Tornqvist M, Fred C, Haglund J, Helleberg H, Paulsson B, Rydberg P. Protein adducts: quantitative and qualitative aspects of their formation, analysis and applications. J Chromatogr B Analyt Technol Biomed Life Sci. 2002; 778:279-308.

8. Skipper PL, Tannenbaum SR. Protein adducts in the molecular dosimetry of chemical carcinogens. Carcinogenesis. 1990; 11:507-518. [PubMed: 2182215]

9. Liebler DC. Proteomic approaches to characterize protein modifications: new tools to study the effects of environmental exposures. Environ Health Perspect. 2002; 110(Suppl 1):3-9. [PubMed: 11834459]

10. Rubino FM, Pitton M, Di FD, Colombi A. Toward an "omic" physiopathology of reactive chemicals: thirty years of mass spectrometric study of the protein adducts with endogenous and xenobiotic compounds. Mass Spectrom Rev. 2009; 28:725-784. [PubMed: 19127566]

11. Sleep D, Belfield GP, Goodey AR. The secretion of human serum albumin from the yeast Saccharomyces cerevisiae using five different leader sequences. Biotechnology (N Y). 1990; 8:4246. [PubMed: 1366511]

12. Sijmons PC, Dekker BM, Schrammeijer B, Verwoerd TC, van den Elzen PJ, Hoekema A. Production of correctly processed human serum albumin in transgenic plants. Biotechnology $(\mathrm{N}$ Y). 1990; 8:217-221. [PubMed: 1366404]

13. Shani M, Barash I, Nathan M, Ricca G, Searfoss GH, Dekel I, Faerman A, Givol D, Hurwitz DR. Expression of human serum albumin in the milk of transgenic mice. Transgenic Res. 1992; 1:195208. [PubMed: 1284483]

14. Barash I, Faerman A, Ratovitsky T, Puzis R, Nathan M, Hurwitz DR, Shani M. Ectopic expression of beta-lactoglobulin/human serum albumin fusion genes in transgenic mice: hormonal regulation and in situ localization. Transgenic Res. 1994; 3:141-151. [PubMed: 8025593]

15. Wu X, Lin Y, Xiong F, Zhou Y, Yu F, Deng J, Huang P, Chen H. The extremely high level expression of human serum albumin in the milk of transgenic mice. Transgenic Res. 2012; 21:1359-1366. [PubMed: 22447034]

16. Hursting SD, Slaga TJ, Fischer SM, DiGiovanni J, Phang JM. Mechanism-based cancer prevention approaches: targets, examples, and the use of transgenic mice. J Natl Cancer Inst. 1999; 91:215225. [PubMed: 10037099]

17. Ma X, Idle JR, Malfatti MA, Krausz KW, Nebert DW, Chen CS, Felton JS, Waxman DJ, Gonzalez FJ. Mouse lung CYP1A1 catalyzes the metabolic activation of 2-amino-1-methyl-6phenylimidazo[4,5-b]pyridine (PhIP). Carcinogenesis. 2007; 28:732-737. [PubMed: 17052995]

18. Cheung C, Gonzalez FJ. Humanized mouse lines and their application for prediction of human drug metabolism and toxicological risk assessment. J Pharmacol Exp Ther. 2008; 327:288-299. [PubMed: 18682571]

19. Sugimura T, Wakabayashi K, Nakagama H, Nagao M. Heterocyclic amines: Mutagens/carcinogens produced during cooking of meat and fish. Cancer Sci. 2004; 95:290-299. [PubMed: 15072585]

20. Su T, Bao Z, Zhang QY, Smith TJ, Hong JY, Ding X. Human cytochrome P450 CYP2A13: Predominant expression in the respiratory tract and its high efficiency metabolic activation of a tobacco-specific carcinogen, 4-(methylnitrosamino)-1-(3-pyridyl)-1-butanone. Cancer Res. 2000; 60:5074-5079. [PubMed: 11016631]

21. Wang Y, Peng L, Bellamri M, Langouet S, Turesky RJ. Mass spectrometric characterization of human serum albumin adducts formed with N-Oxidized metabolites of 2-amino-1methylphenylimidazo[4,5-b]pyridine in human plasma and hepatocytes. Chem Res Toxicol. 2015; 28:1049-1059.

22. Peng L, Turesky RJ. Mass spectrometric characterization of 2-amino-1-methyl-6phenylimidazo[4,5-b]pyridine $\mathrm{N}$-oxidized metabolites bound at $\mathrm{Cys}^{34}$ of human serum albumin. Chem Res Toxicol. 2011; 24:2004-2017. [PubMed: 21916490] 
23. Pace CN, Vajdos F, Fee L, Grimsley G, Gray T. How to measure and predict the molar absorption coefficient of a protein. Protein Sci. 1995; 4:2411-2423. [PubMed: 8563639]

24. Ding XX, Coon MJ. Immunochemical characterization of multiple forms of cytochrome P-450 in rabbit nasal microsomes and evidence for tissue-specific expression of P-450s NMa and NMb. Mol Pharmacol. 1990; 37:489-496. [PubMed: 2109181]

25. Peng L, Turesky RJ. Optimizing proteolytic digestion conditions for the analysis of serum albumin adducts of 2-amino-1-methyl-6-phenylimidazo[4,5-b]pyridine, a potential human carcinogen formed in cooked meat. J Proteomics. 2014; 103:267-278. [PubMed: 24698664]

26. Peng L, Dasari S, Tabb DL, Turesky RJ. Mapping serum albumin adducts of the food-borne carcinogen 2-amino-1-methyl-6-phenylimidazo[4,5- $b$ ]pyridine by data-dependent tandem mass spectrometry. Chem Res Toxicol. 2012; 25:2179-2193. [PubMed: 22827630]

27. Tabb DL, Fernando CG, Chambers MC. MyriMatch: highly accurate tandem mass spectral peptide identification by multivariate hypergeometric analysis. J Proteome Res. 2007; 6:654-661. [PubMed: 17269722]

28. Gorski K, Carneiro M, Schibler U. Tissue-specific in vitro transcription from the mouse albumin promoter. Cell. 1986; 47:767-776. [PubMed: 3779841]

29. Pinkert CA, Ornitz DM, Brinster RL, Palmiter RD. An albumin enhancer located $10 \mathrm{~kb}$ upstream functions along with its promoter to direct efficient, liver-specific expression in transgenic mice. Genes \& Development. 1987; 1:268-276. [PubMed: 3678824]

30. Bytzek AK, Boeck K, Hermann G, Hann S, Keppler BK, Hartinger CG, Koellensperger G. LCand CZE-ICP-MS approaches for the in vivo analysis of the anticancer drug candidate sodium trans-[tetrachloridobis(1H-indazole)ruthenate(III)] (KP1339) in mouse plasma. Metallomics. 2011; 3:1049-1055. [PubMed: 21935553]

31. Funk WE, Li H, Iavarone AT, Williams ER, Riby J, Rappaport SM. Enrichment of cysteinyl adducts of human serum albumin. Anal Biochem. 2010; 400:61-68. [PubMed: 20074543]

32. Peters T Jr. Serum albumin. Adv Clin Chem. 1970; 13:37-111. [PubMed: 4919632]

33. He Y, Ning T, Xie T, Qiu Q, Zhang L, Sun Y, Jiang D, Fu K, Yin F, Zhang W, Shen L, Wang H, Li J, Lin Q, Sun Y, Li H, Zhu Y, Yang D. Large-scale production of functional human serum albumin from transgenic rice seeds. Proc Natl Acad Sci U S A. 2011; 108:19078-19083. [PubMed: 22042856]

34. Stewart AJ, Blindauer CA, Berezenko S, Sleep D, Tooth D, Sadler PJ. Role of Tyr84 in controlling the reactivity of $\mathrm{Cys}^{34}$ of human albumin. FEBS J. 2005; 272:353-362. [PubMed: 15654874]

35. Peng L, Turesky RJ. Capturing labile sulfenamide and sulfinamide serum albumin adducts of carcinogenic arylamines by chemical oxidation. Anal Chem. 2013; 85:1065-1072. [PubMed: 23240913]

36. LeBlanc A, Shiao TC, Roy R, Sleno L. Absolute Quantitation of NAPQI-Modified Rat Serum Albumin by LC-MS/MS: Monitoring acetaminophen covalent binding in vivo. Chem Res Toxicol. 2014; 27:1632-1639. [PubMed: 25168029]

37. Switzar L, Kwast LM, Lingeman H, Giera M, Pieters RH, Niessen WM. Identification and quantification of drug-albumin adducts in serum samples from a drug exposure study in mice. $\mathrm{J}$ Chromatogr B Analyt Technol Biomed Life Sci. 2013; 917-918:53-61.

38. Dongré AR, Jones JL, Somogyi Á, Wysocki VH. Influence of peptide composition, gas-phase basicity, and chemical modification on fragmentation efficiency: Evidence for the Mobile Proton Model. J Am Chem Soc. 1996; 118:8365-8374.

39. Kleinova M, Belgacem O, Pock K, Rizzi A, Buchacher A, Allmaier G. Characterization of cysteinylation of pharmaceutical-grade human serum albumin by electrospray ionization mass spectrometry and low-energy collision-induced dissociation tandem mass spectrometry. Rapid Commun Mass Spectrom. 2005; 19:2965-2973. [PubMed: 16178042] 


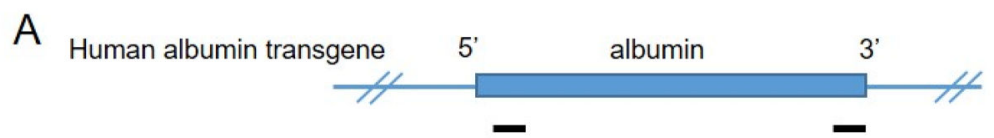

B

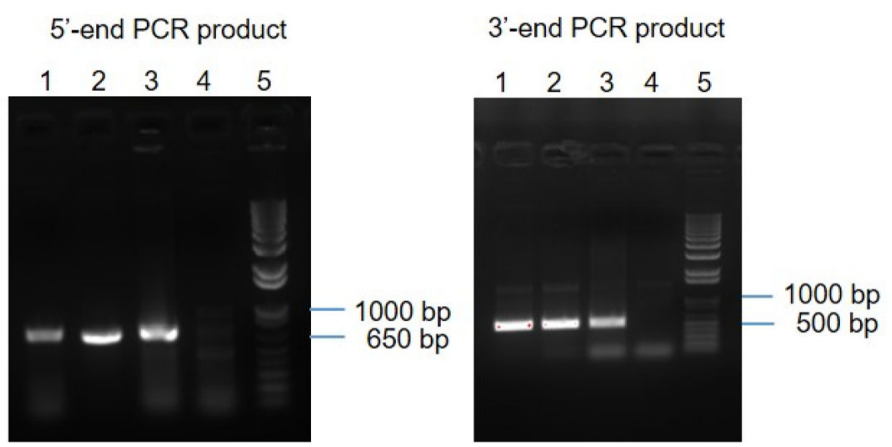

Figure 1.

Identification of transgenic founder mice by genomic PCR analyses. (A) Schematic representation of the human albumin transgene showing the positions of the two genomic PCR amplicons (black bars) used for genotyping. The two sets of primers used for genotyping are described in Methods. (B) Agarose-gel electrophoresis analysis of the $5^{\prime}$-end and 3 '-end genomic PCR products. Genomic PCR products from tail DNA samples of the three identified transgenic founder mice (lanes $1-3$, for transgenic lines $1-3$, respectively) and a wild-type control mouse (lane 4) were analyzed, along with a 1-kb plus DNA size marker (lane 5). The calculated size of the PCR amplicons was 719 bp (5'-end, primer set \#1) and 545 bp (3'-end, primer set \#2), respectively. 
A

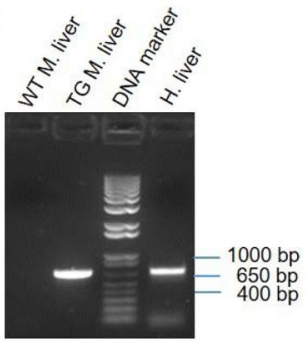

C

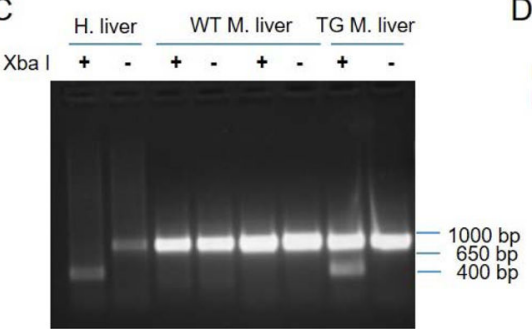

B

$\mathrm{D}$
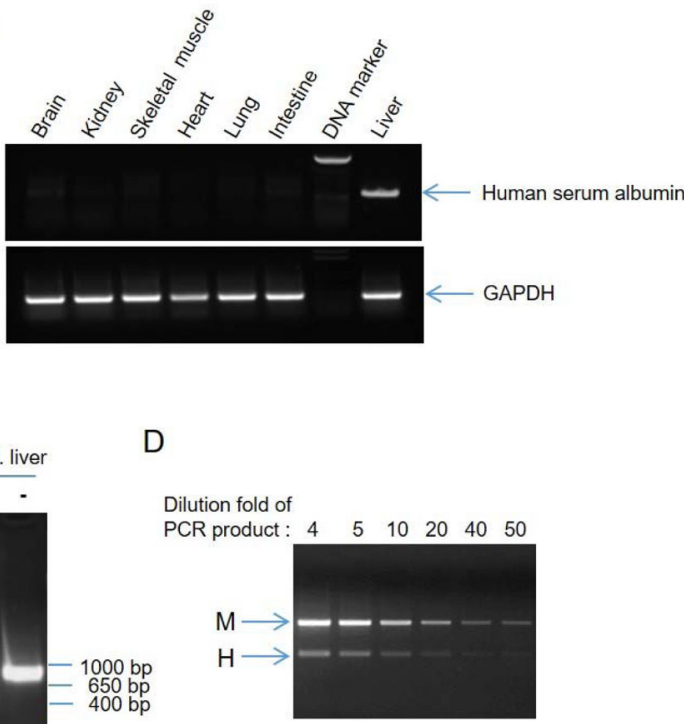

Figure 2.

Detection of human albumin transcripts in the transgenic mice. (A). RNA samples of wildtype [WT] and human albumin transgenic [TG] mouse [M] livers and a human $[\mathrm{H}]$ liver were analyzed by RT-PCR using primers specific for human albumin. The calculated size of the PCR amplicon was $691 \mathrm{bp}$. Selected fragments of the 1-kb plus DNA size marker are indicated. (B). RNA samples from majors organs (as indicated) of the transgenic mice (line 1) were analyzed by RT-PCR with either the human albumin specific primers (top) or primers for mouse GAPDH (bottom). A 100-bp (top) or a 1-kb plus (bottom) DNA size marker was included. (C). The presence of human albumin transcript in the transgenic mouse liver was further verified by Xba I digestion of RT-PCR products amplified using primers common to both human and mouse albumin transcripts. PCR products from human liver RNA, wild-type mouse liver RNA, and transgenic mouse liver RNA were analyzed. $\mathrm{Xba}$ I cut PCR products derived from human but not mouse albumin transcripts. Selected fragments of the 1-kb plus DNA size marker are indicated. (D) Relative abundance of PCR products derived from mouse and human albumin transcripts in the transgenic mouse liver. PCR products from transgenic mouse liver (line 1) were serially diluted prior to electrophoretic analysis, in order to facilitate estimation of the relative intensities of the bands corresponding to mouse $[\mathrm{M}]$ and human $[\mathrm{H}]$ albumin transcripts. Results from densitometric measurements indicated an intensity ratio of $~ 1: 5$ (H:M). 


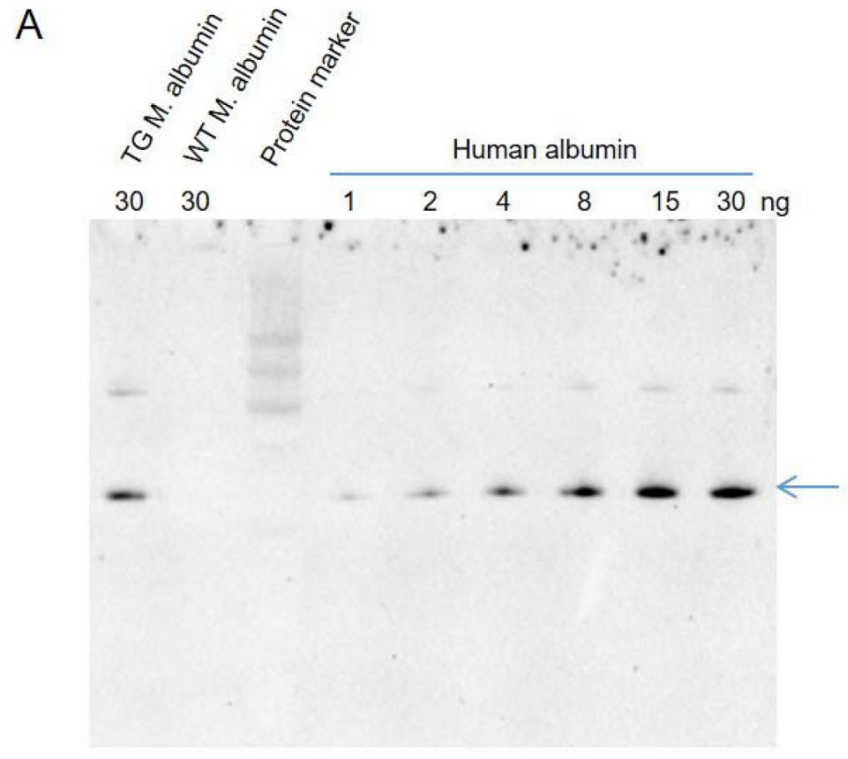

B
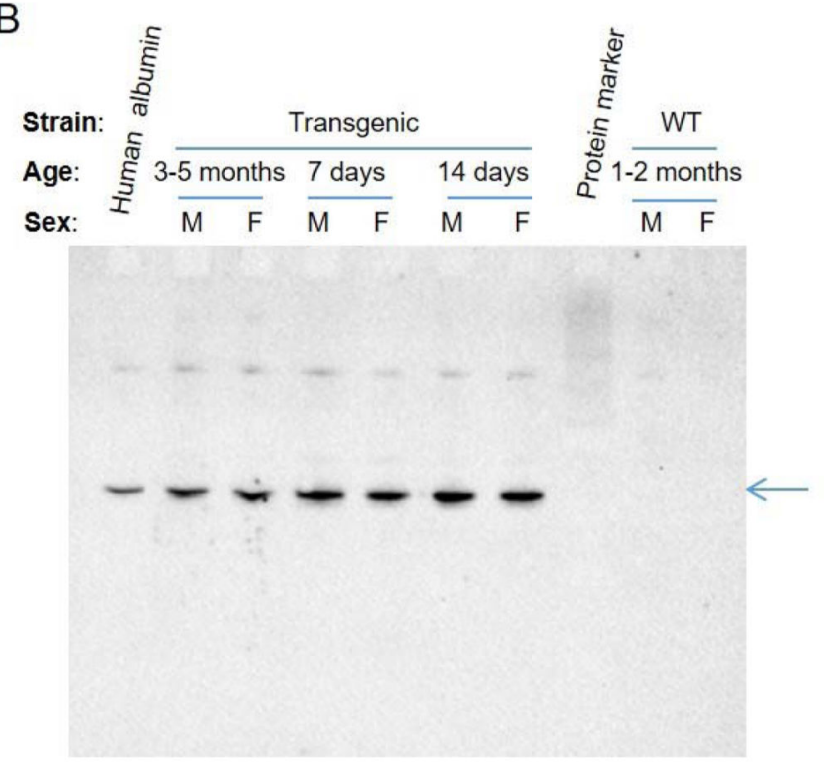

Figure 3.

Immunoblot detection of transgenic human albumin protein. (A). Purified total (human + mouse) serum albumin of human albumin-transgenic [TG] mice and wild-type [WT] mice, along with a human $[\mathrm{H}]$ serum albumin standard at various amounts (as indicated), were analyzed with use of an anti-human albumin antibody. A Bio-Rad Precision Plus Protein Standard mix was used as a size marker. The amount of human albumin detected in $30 \mathrm{ng}$ of total albumin from the transgenic mouse serum (line 1) was estimated, based on densitometric analysis, to be $\sim 6 \mathrm{ng}$, or $\sim 20 \%$ of the total. Typical results of two experiments. (B). Detection of human albumin in the serum of both male and female transgenic mice (line 1) at various ages ( 7 or 14 days or 3-5 months). Serum samples ( $1 \mu \mathrm{g}$ protein/lane; each sample pooled from three mice) were analyzed with the anti-human albumin antibody. A 
human albumin standard ( 18 ng protein) and serum samples of male $[\mathrm{M}]$ and female $[\mathrm{F}]$ wild-type mice (1-2 months old) were also analyzed, as controls. Arrow: human albumin. 


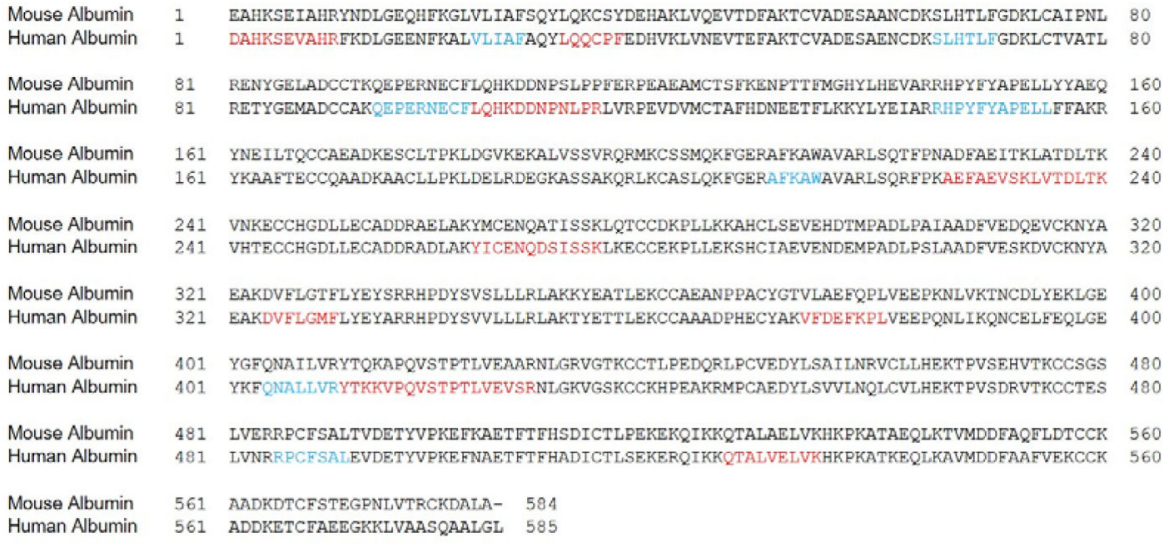

Figure 4.

Alignment of amino acid sequences of mature mouse and human albumins. Peptides identified in the transgenic mouse serum albumin that are unique to human albumin are indicated in red; peptides identified in the transgenic mouse serum albumin that are shared by human and mouse albumins are indicated in blue. 

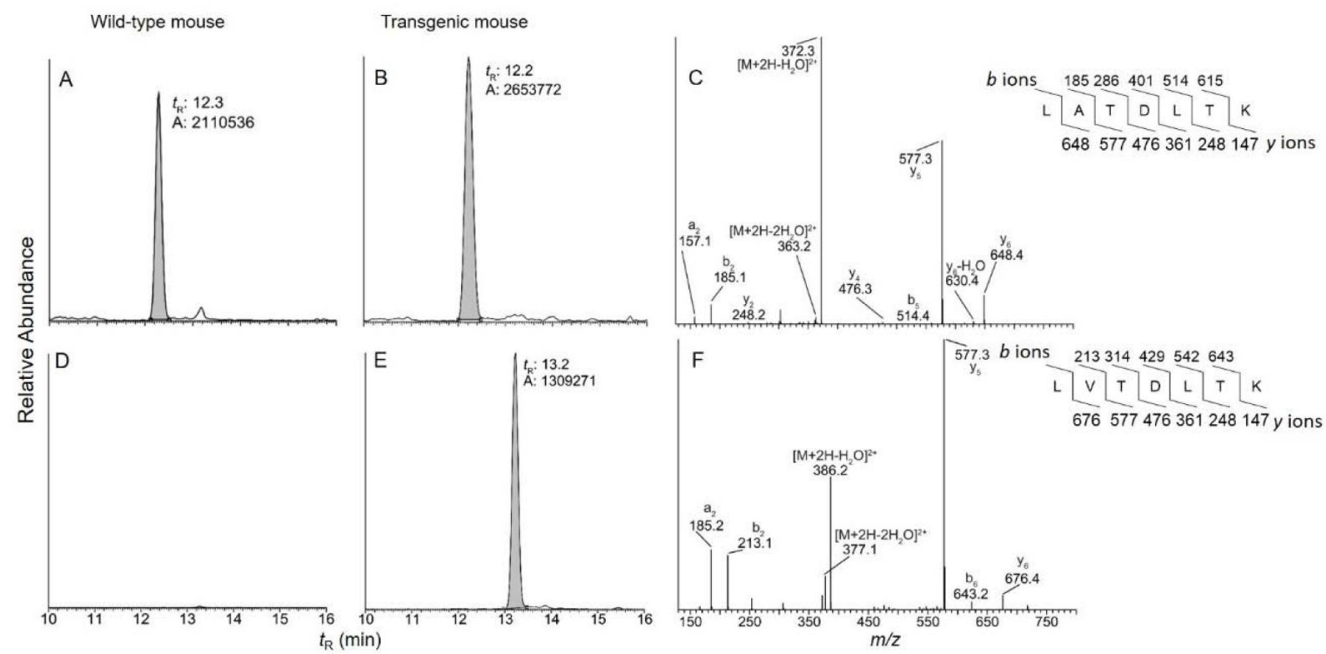

Figure 5.

Mass chromatograms of ${ }^{234}$ LATDLTK $^{240}$ and ${ }^{234}$ LVTDLTK $^{240}$. (A, B). Detection of ${ }^{234}$ LATDLTK $^{240}\left([\mathrm{M}+2 \mathrm{H}]^{2+}\right.$ at $\mathrm{m} / z 381.2>372.3$, 577.3), representing mouse albumin; (D, E). Detection of ${ }^{234}$ LVTDLTK $^{240}\left([\mathrm{M}+2 \mathrm{H}]^{2+}\right.$ at $\left.\mathrm{m} / z 395.2>386.2,577.4\right)$, representing human albumin;. (C, F). Corresponding mass spectra of ${ }^{234}$ LATDLTK $^{240}$ (C) and ${ }^{234} \operatorname{LVTDLTK}^{240}(\mathrm{~F})$. Serum albumin from wild-type (A, D) and transgenic mice (B, E) was digested with trypsin and chymotrypsin. The ion intensities were normalized to the same scale for wild type and transgenic mice albumin. 


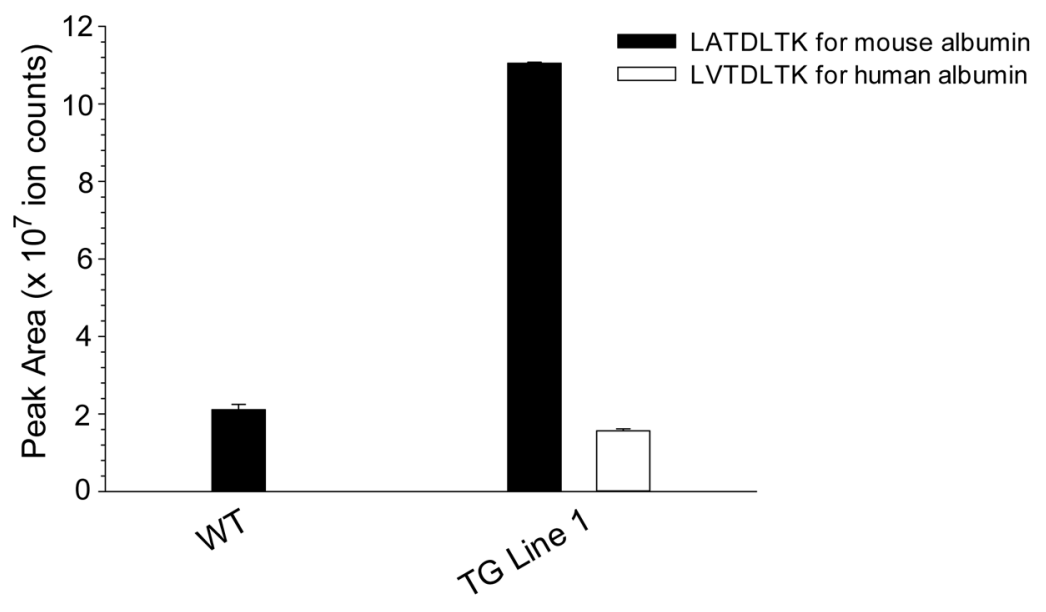

Figure 6.

Estimates of the relative abundance of ${ }^{234}{ }^{2}$ ATDLTK $^{240}$ and ${ }^{234}$ LVTDLTK $^{240}$. Peak areas of ion counts from UPLC-MS/MS analysis of (black bar) ${ }^{234}$ LATDLTK $^{240}\left([\mathrm{M}+2 \mathrm{H}]^{2+}\right.$ at $\mathrm{m} / z$ $381.2>372.3,577.3)$ and (white bar) ${ }^{234} \operatorname{LVTDLTK}^{240}\left([\mathrm{M}+2 \mathrm{H}]^{2+}\right.$ at $\mathrm{m} / z 395.2>386.2$, 577.4), representing mouse and human albumin, respectively, are shown. Serum albumin samples purified from wild-type and transgenic female mice (line 1) were analyzed, as depicted in Figure 5. The results represent means $\pm \operatorname{SD}(n=3)$. 


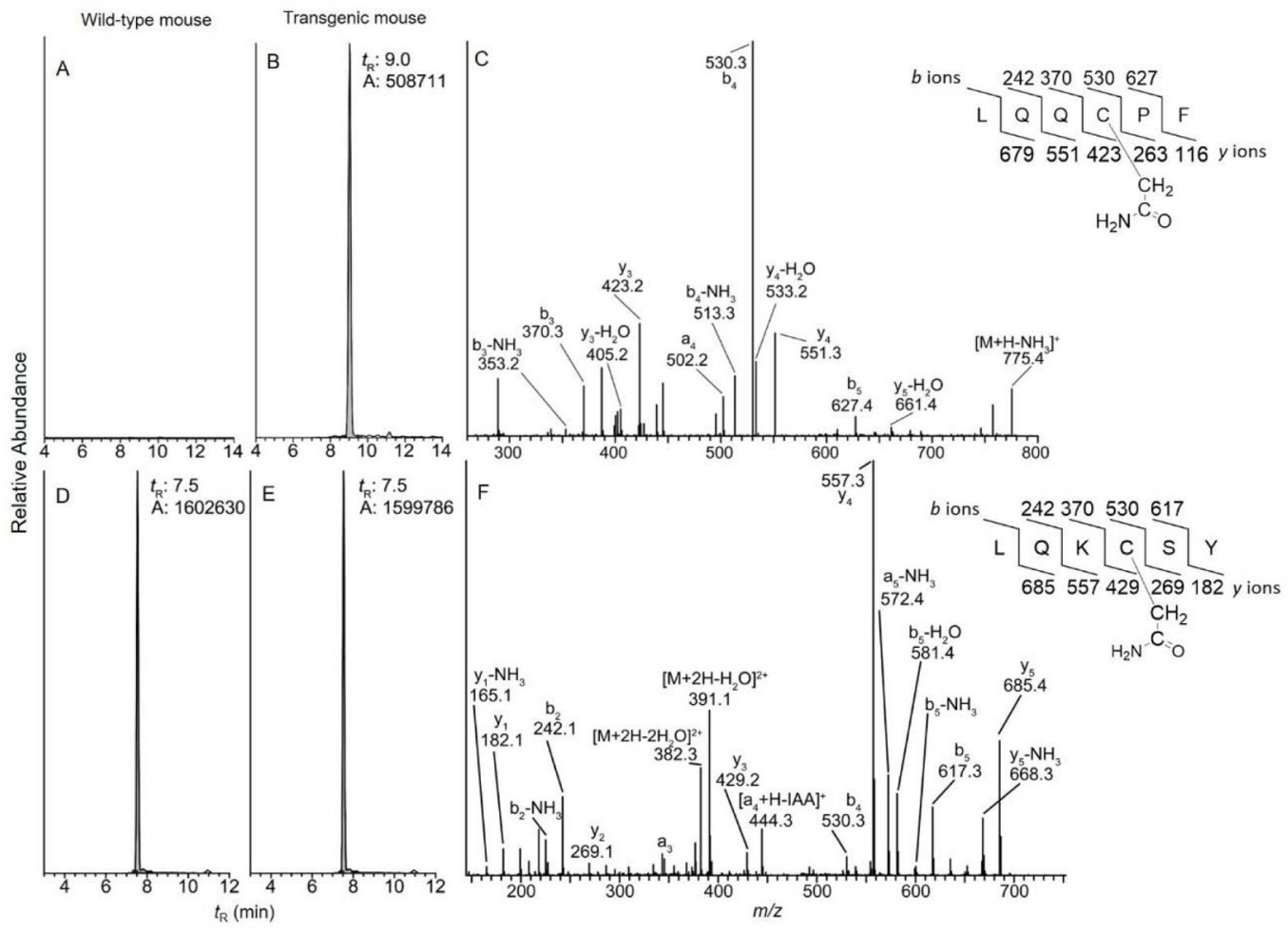

Figure 7.

Mass chromatograms of ${ }^{31} \mathrm{LQQC}^{*}[\mathrm{IAA}] \mathrm{PF}^{36}$ and ${ }^{31} \mathrm{LQKC}{ }^{*}[\mathrm{IAA}] \mathrm{SY}^{36}$. (A, B). Detection of ${ }^{31}{ }^{\mathrm{LQQ}} \mathrm{C}^{*[\mathrm{IAA}]} \mathrm{PF}^{36}\left([\mathrm{M}+\mathrm{H}]^{+}\right.$at $\left.\mathrm{m} / z 792.5>530.3\right)$, representing human albumin;. (D, E). Detection of ${ }^{31} \mathrm{LQKC}^{*[\mathrm{IAA}]} \mathrm{SY}^{36}\left([\mathrm{M}+2 \mathrm{H}]^{2+}\right.$ at $\left.\mathrm{m} / z 399.9>557.3\right)$, representing mouse albumin; (C, F). Corresponding mass spectra and proposed diagnostic product ions of ${ }^{31} \mathrm{LQQC}^{*[\mathrm{IAA}]} \mathrm{PF}^{36}(\mathrm{C})$ and ${ }^{31} \mathrm{LQKC}{ }^{*[\mathrm{IAA}]} \mathrm{SY}^{36}(\mathrm{~F})$. Serum albumin from wild-type (A, D) and transgenic mice $(\mathrm{B}, \mathrm{E})$ was digested with trypsin and chymotrypsin. $(\mathrm{C}, \mathrm{F})$. The ion intensities were normalized to the same scale for wild type and transgenic mice albumins. 

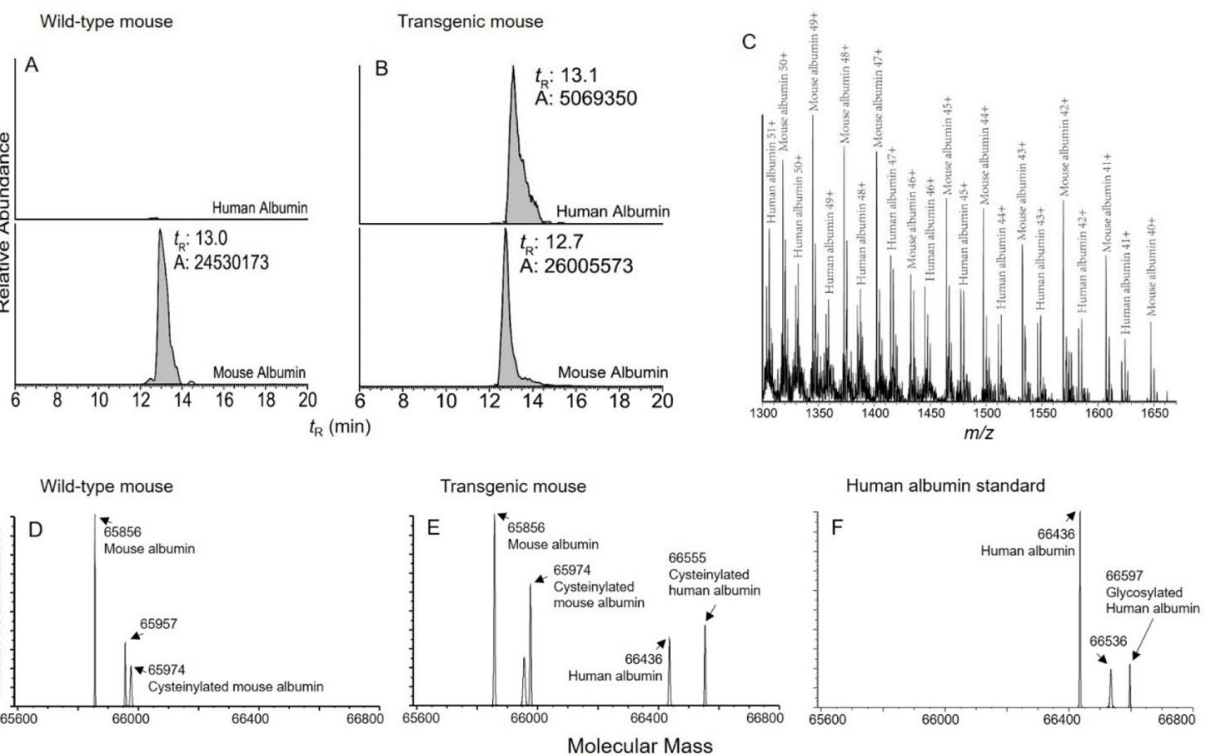

Figure 8.

Mass chromatograms of human and mouse serum albumin. Intact serum albumin of wildtype (A) and transgenic mice (B) was analyzed using UPLC-MS as described in Materials and Methods. The reconstructed ion chromatograms and peak areas of the top three ions for human $\left([\mathrm{M}+47 \mathrm{H}]^{47+}\right.$ at $\mathrm{m} / z$ 1414.6, $[\mathrm{M}+46 \mathrm{H}]^{46+}$ at $\mathrm{m} / z 1445.3,[\mathrm{M}+44 \mathrm{H}]^{44+}$ at $\left.\mathrm{m} / z 1510.9\right)$ and mouse albumin $\left([\mathrm{M}+47 \mathrm{H}]^{47+}\right.$ at $\mathrm{m} / z$ 1402.2, $[\mathrm{M}+46 \mathrm{H}]^{46+}$ at $\mathrm{m} / z 1432.6,[\mathrm{M}+44 \mathrm{H}]^{44+}$ at $\mathrm{m} / z$ 1497.7) are shown. (C) Raw mass spectra and proposed charged ion states. (D-F). Deconvoluted results of the mass spectral data of intact albumin from wild-type mice (D), transgenic mice $(\mathrm{E})$, and a human albumin standard $(\mathrm{F})$. The ion intensities are normalized to the same scale for mouse and human albumins. 


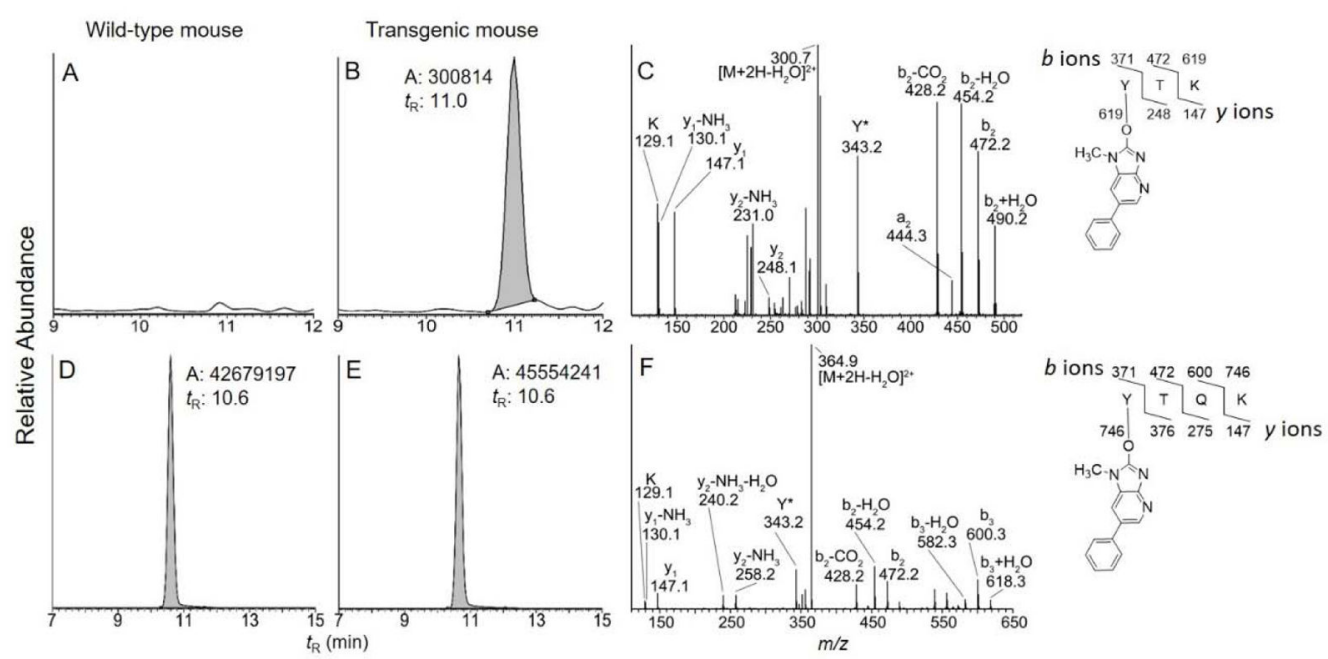

Figure 9.

Mass chromatograms of ${ }^{411} \mathrm{Y}^{*}[$ desaminoPhIP $] \mathrm{TK}^{413}$ and ${ }^{411} \mathrm{Y}^{*}\left[\right.$ desaminoPhIP] $\mathrm{TQK}^{414}$. (A, B). Detection of ${ }^{411} \mathrm{Y}^{*}[$ desaminoPhIP $] \mathrm{TK}^{413}\left([\mathrm{M}+2 \mathrm{H}]^{2+}\right.$ at $\mathrm{m} / \mathrm{z} 309.7>343.2$, 428.3) from human albumin modified with $\mathrm{NO}_{2}-\mathrm{PhIP}: \mathrm{NO}_{2}-\left[{ }^{2} \mathrm{H}_{5}\right]-\mathrm{PhIP}$; (D, E). Detection of ${ }^{411} \mathrm{Y}^{*}[$ desaminoPhIP $] \mathrm{TQK}^{414}\left([\mathrm{M}+2 \mathrm{H}]^{2+}\right.$ at $\left.\mathrm{m} / \mathrm{z} 373.8>364.9\right)$ from mouse albumin modified with $\mathrm{NO}_{2}-\mathrm{PhIP}: \mathrm{NO}_{2}-\left[{ }^{2} \mathrm{H}_{5}\right]$-PhIP; $(\mathrm{C}, \mathrm{F})$. The corresponding mass spectra and proposed diagnostic product ions of ${ }^{411} \mathrm{Y}^{*}[$ desaminoPhIP $] \mathrm{TK}^{413}(\mathrm{C})$ and ${ }^{411} \mathrm{Y}^{*}\left[\right.$ desaminoPhIP] $\mathrm{TQK}{ }^{414}(\mathrm{~F})$. PhIP-modified albumin from wild type (A, D) and transgenic $(\mathrm{B}, \mathrm{E})$ mice was digested with trypsin and chymotrypsin. The ion intensities are normalized to the same scale for wild type and transgenic mice. 


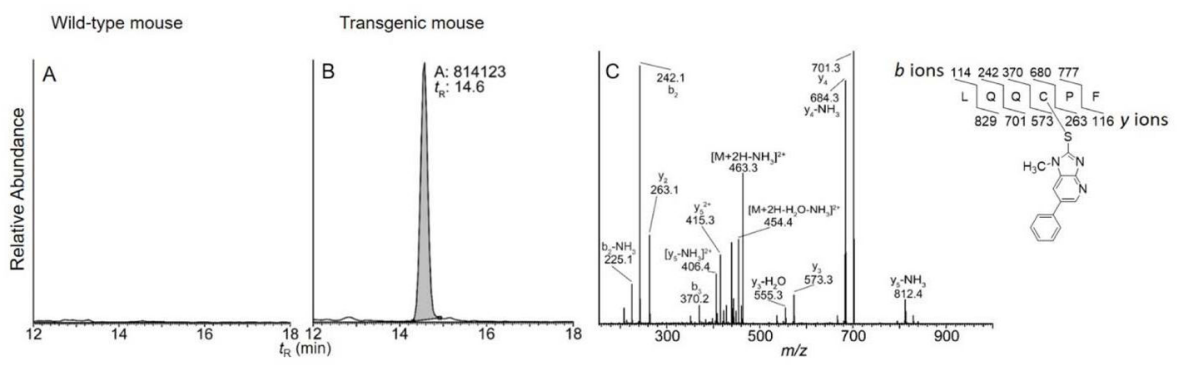

Figure 10.

Mass chromatograms of ${ }^{31} \mathrm{LQQC}^{*}[$ desaminoPhIP $] \mathrm{PFE}^{37}$. (A, B). Detection of ${ }^{31} \mathrm{LQQC}^{*}[$ desaminoPhIP $] \mathrm{PFE}^{37}\left([\mathrm{M}+2 \mathrm{H}]^{2+}\right.$ at $\left.\mathrm{m} / z 471.7>242.1,684.3,701.3\right)$ from human albumin modified with $\mathrm{NO}_{2}-\mathrm{PhIP}: \mathrm{NO}_{2}-\left[{ }^{2} \mathrm{H}_{5}\right]-\mathrm{PhIP}$. PhIP-modified albumin from wild type (A) and transgenic (B) mice was digested with trypsin and chymotrypsin; (C). The corresponding mass spectrum and proposed diagnostic product ions of ${ }^{31}{ }^{L Q Q C}{ }^{*}\left[\right.$ desaminoPhIP] $\mathrm{PFE}^{37}$. The ion intensities are normalized to the same scale for wild type and transgenic mice albumins. 

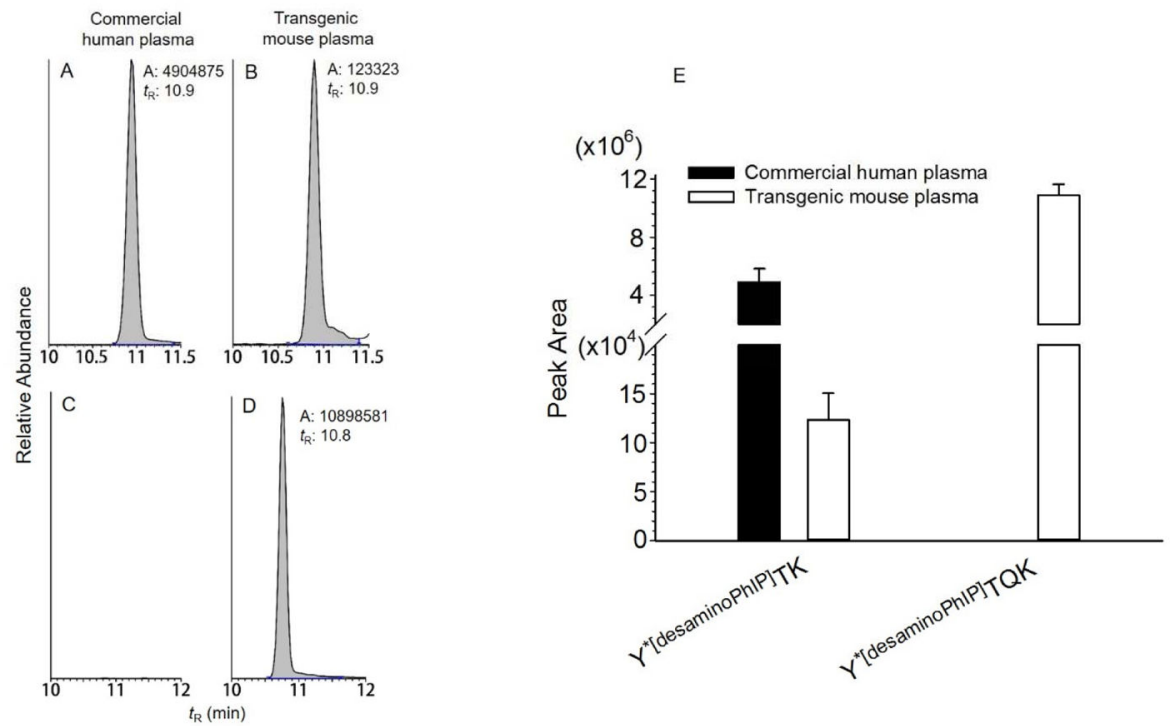

Figure 11.

Mass chromatograms of human ${ }^{411} \mathrm{Y}^{*}\left[\right.$ desaminoPhIP] $\mathrm{TK}^{413}$ and mouse ${ }^{411} \mathrm{Y}^{*}$ [desaminoPhIP] $\mathrm{TQK}^{414}$. Human ${ }^{411} \mathrm{Y}^{*}$ [desaminoPhIP] $\mathrm{TK}^{413}\left([\mathrm{M}+2 \mathrm{H}]^{2+}\right.$ at $\mathrm{m} / \mathrm{Z}$ 309.7 > 343.2, 428.3) were detected by UPLC-MS/MS analysis in both (A) commercial human plasma and (B) transgenic mouse plasma after $\mathrm{NO}_{2}-\mathrm{PhIP}$ treatment and trypsin and chymotrypsin digestion. Mouse ${ }^{411} \mathrm{Y}^{*}[$ desaminoPhIP $] \mathrm{TQK}^{414}\left([\mathrm{M}+2 \mathrm{H}]^{2+}\right.$ at $\mathrm{m} / \mathrm{z} 373.8$ >

364.9) was only detected in (D) transgenic mouse plasma (line 2) but not in (C) commercial human plasma. The relative abundance of ${ }^{411} \mathrm{Y}^{*}\left[\right.$ desaminoPhIP] $\mathrm{TK}^{413}$

and ${ }^{411} \mathrm{Y}^{*}\left[\right.$ desaminoPhIP] $\mathrm{TQK}^{414}$ was estimated with the peak areas of ${ }^{411} \mathrm{Y}^{*}$ [desaminoPhIP] $\mathrm{TK}^{413}\left([\mathrm{M}+2 \mathrm{H}]^{2+}\right.$ at $\left.\mathrm{m} / \mathrm{z} 309.7>343.2,428.3\right)$ and ${ }^{411} \mathrm{Y}^{*}\left[\right.$ desaminoPhIP] $\mathrm{TQK}^{414}\left([\mathrm{M}+2 \mathrm{H}]^{2+}\right.$ at $\left.\mathrm{m} / \mathrm{z} 373.8>364.9\right)$ derived from (black bar) commercial human plasma and (white bar) transgenic mouse plasma (line \#2). The results (E) represent the mean $\pm \mathrm{SD}(\mathrm{n}=3)$. 

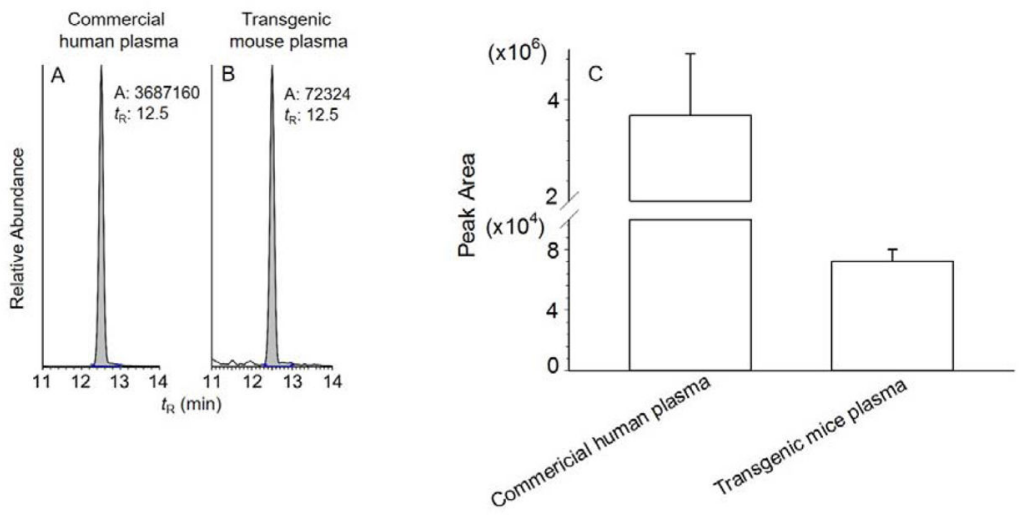

Figure 12.

Mass chromatograms of human ${ }^{31} \mathrm{LQQC}^{*}\left[\right.$ desaminoPhIP] $\mathrm{PFE}^{37}$.

Human ${ }^{31}{ }^{\mathrm{LQQQ}}{ }^{*}\left[\right.$ desaminoPhIP] $\mathrm{PFE}^{37}\left([\mathrm{M}+2 \mathrm{H}]^{2+}\right.$ at $\left.\mathrm{m} / z 471.7>242.1,684.3,701.3\right)$ formed in the transgenic mouse plasma pretreated with $\mathrm{NO}_{2}$-PhIP was detected by UPLC-MS/MS analysis. The mass chromatograms of ${ }^{31} \mathrm{LQQC}{ }^{*}\left[\right.$ desaminoPhIP] $\mathrm{PFE}^{37}$ derived from the $\mathrm{NO}_{2}$ PhIP-modified albumin of both (A) commercial human plasma and (B) transgenic mouse plasma (line \#2) are shown and the peak areas (E) of ion counts of LQQC ${ }^{*[\text { desaminoPhIP] } P F E}$ $\left([\mathrm{M}+2 \mathrm{H}]^{2+}\right.$ at $\left.\mathrm{m} / \mathrm{z} 471.7>242.1,684.3,701.3\right)$ derived from commercial human and transgenic mouse plasma (line \#2) are compared. The results represent the mean $\pm \operatorname{SD}(n=3)$. 


\section{Table 1}

A list of human albumin peptides identified in purified albumin from the serum of transgenic mice. Peptides were identified in tryptic/chymotryptic digests of albumins by data dependent scanning MS.

\begin{tabular}{|c|c|c|c|c|}
\hline Peptides & Charge states & $m / z$ & Figures & Domains \\
\hline \multicolumn{5}{|l|}{ Peptide sequences unique to human albumin } \\
\hline H2N- ${ }^{1}$ DAHKSEVAHR ${ }^{10}-\mathrm{COOH}$ & {$[\mathrm{M}+2 \mathrm{H}]^{2+}$} & 575.6 & S2 & IA \\
\hline $\mathrm{H} 2 \mathrm{~N}-{ }^{31} \mathrm{LQQC}^{*[\mathrm{IAA}]} \mathrm{PF}^{36}-\mathrm{COOH}$ & {$[\mathrm{M}+\mathrm{H}]^{+}$} & 792.4 & 7 & IA \\
\hline $\mathrm{H} 2 \mathrm{~N}-{ }^{31} \mathrm{LQQC}^{*}[\mathrm{SO} 3 \mathrm{H}] \mathrm{PFEDHVK}^{41}-\mathrm{COOH}$ & {$[\mathrm{M}+2 \mathrm{H}]^{2+}$} & 696.8 & S1 & IA \\
\hline H2N- ${ }^{103}$ LQHKDDNPNLPR ${ }^{114}$-COOH & {$[\mathrm{M}+3 \mathrm{H}]^{3+}$} & 483.2 & S3 & IB \\
\hline H2N-226AEFAEVSKL ${ }^{234}$-COOH & {$[\mathrm{M}+2 \mathrm{H}]^{2+}$} & 497.6 & S4 & IIA \\
\hline H2N-234 LVTDLTK ${ }^{240}-\mathrm{COOH}$ & {$[\mathrm{M}+2 \mathrm{H}]^{2+}$} & 395.2 & 5 & IIA \\
\hline $\mathrm{H} 2 \mathrm{~N}-{ }^{263}{ }^{2} I_{C E N Q D S I S S K}{ }^{274}-\mathrm{COOH}$ & {$[\mathrm{M}+2 \mathrm{H}]^{2+}$} & 722.8 & S5 & IIA \\
\hline $\mathrm{H} 2 \mathrm{~N}-{ }^{324} \mathrm{DVFLGMF}^{330}-\mathrm{COOH}$ & {$[\mathrm{M}+\mathrm{H}]^{+}$} & 829.0 & S6 & IIB \\
\hline H2N- ${ }^{373}$ VFDEFKPL ${ }^{380}-\mathrm{COOH}$ & {$[\mathrm{M}+2 \mathrm{H}]^{2+}$} & 498.1 & S7 & IIB \\
\hline $\mathrm{H} 2 \mathrm{~N}-{ }^{411} \mathrm{YTK}^{413}-\mathrm{COOH}$ & {$[\mathrm{M}+\mathrm{H}]^{+}$} & 411.5 & S8 & IIIA \\
\hline H2N- ${ }^{414}$ KVPQVSTPTLVEVSR ${ }^{428}$-COOH & {$[\mathrm{M}+3 \mathrm{H}]^{3+}$} & 547.7 & S9 & IIIA \\
\hline H2N_526 QTALVELVK ${ }^{534}$-COOH & {$[\mathrm{M}+2 \mathrm{H}]^{2+}$} & 501.1 & S10 & IIIB \\
\hline \multicolumn{5}{|c|}{ Peptide sequences shared by human albumin and mouse albumin } \\
\hline H2N-23 VLIAF $^{27}-\mathrm{COOH}$ & {$[\mathrm{M}+\mathrm{H}]^{+}$} & 562.7 & - & IA \\
\hline $\mathrm{H} 2 \mathrm{~N}-{ }^{65} \mathrm{SLHTLF}^{70}-\mathrm{COOH}$ & {$[\mathrm{M}+\mathrm{H}]^{+}$} & 717.8 & - & IA \\
\hline $\mathrm{H} 2 \mathrm{~N}-{ }^{94} \mathrm{QEPERNECF}{ }^{70}-\mathrm{COOH}$ & {$[\mathrm{M}+2 \mathrm{H}]^{2+}$} & 576.6 & - & IA \\
\hline H2N- ${ }^{145}$ RHPYFYAPELL ${ }^{155}-\mathrm{COOH}$ & {$[\mathrm{M}+3 \mathrm{H}]^{3+}$} & 469.6 & - & IB \\
\hline $\mathrm{H} 2 \mathrm{~N}-{ }^{210} \mathrm{AFKAW}{ }^{155}-\mathrm{COOH}$ & {$[\mathrm{M}+\mathrm{H}]^{+}$} & 622.7 & - & IIA \\
\hline $\mathrm{H} 2 \mathrm{~N}-{ }^{404} \mathrm{QNALLVR}{ }^{410}-\mathrm{COOH}$ & {$[\mathrm{M}+\mathrm{H}]^{+}$} & 814.0 & - & IIIA \\
\hline H2N-485 RPCFSAL ${ }^{491}-\mathrm{COOH}$ & {$[\mathrm{M}+2 \mathrm{H}]^{2+}$} & 395.2 & - & IIIA \\
\hline
\end{tabular}

